\title{
Ditopic receptors containing urea groups for solvent extraction of $\mathrm{Cu}(\mathrm{II})$ salts $^{\dagger}$
}

\author{
Israel Carreira-Barral ${ }^{\mathrm{a}}$, Marta Mato-Iglesias ${ }^{\mathrm{a}}$, Andrés de Blas ${ }^{\mathrm{a}}$, Carlos Platas-Iglesias ${ }^{\mathrm{a}}$, Peter A. \\ Tasker $^{\mathrm{b}}$ and David Esteban-Gómez ${ }^{\mathrm{a}}$ \\ ${ }^{a}$ Universidade da Coruña, Centro de Investigacións Científicas Avanzadas (CICA) and Departamento de Química \\ Fundamental, Facultade de Ciencias, 15071, A Coruña, Galicia, Spain \\ ${ }^{b}$ The School of Chemistry at Edinburgh, West Mains Road, Edinburgh, EH9 3JJ, UK
}

Dalton Transactions Volume 46, Issue 10, pages 3192-3206, 14 March 2017

Received 10 January 2017, Accepted 15 February 2017, First published 15 February 2017

\section{How to cite:}

Ditopic receptors containing urea groups for solvent extraction of $\mathrm{Cu}(\mathrm{II})$ salts. I. Carreira-Barral, M. Mato-Iglesias, A. de Blas, C. Platas-Iglesias, P. A. Tasker and D. Esteban-Gómez, Dalt. Trans., 2017, 46, 3192-3206. DOI: 10.1039/C7DT00093F.

\begin{abstract}
The ditopic receptor $\mathbf{L}^{3}$ [1-(2-((7-(4-(tert-butyl)benzyl)-1,4,7,10-tetraazacyclododecan-1-yl)methyl)phenyl)3-(3-nitrophenyl)urea] containing a macrocyclic cyclen unit for $\mathrm{Cu}(\mathrm{II})$-coordination and a urea moiety for anion binding was designed for recognition of metal salts. The X-ray structure of $\left[\mathrm{CuL}^{3}\left(\mathrm{SO}_{4}\right)\right]$ shows that the sulfate anion is involved in cooperative binding via coordination to the metal ion and hydrogen-bonding to the urea unit. This behaviour is similar to that observed for the related receptor $\mathbf{L}^{1}$ [1-(2-((bis(pyridin-2ylmethyl)amino)methyl)phenyl)-3-(3-nitrophenyl)urea], which forms a dimeric $\left[\mathrm{CuL}^{\mathbf{1}}\left(\mu-\mathrm{SO}_{4}\right)\right]_{2}$ structure in the solid state. In contrast, the single crystal X-ray structure of $\left[\mathrm{ZnL}^{3}\left(\mathrm{NO}_{3}\right)_{2}\right]$ contains a $1: 2$ complex (metal : anion) where one anion coordinates to the metal and the other is hydrogen-bonded to the urea group. Spectrophotometric titrations performed for the $\left[\mathrm{CuL}^{3}\left(\mathrm{OSMe}_{2}\right)\right]^{2+}$ complex indicate that this system is able to bind a wide range of anions with an affinity sequence: $\mathrm{MeCO}_{2}^{-}>\mathrm{Cl}^{-}>\mathrm{H}_{2} \mathrm{PO}_{4}{ }^{-}>\mathrm{Br}^{-}>\mathrm{NO}_{2}{ }^{-}>\mathrm{HSO}_{4}{ }^{-}>$ $\mathrm{NO}_{3}{ }^{-}$. Lipophilic analogues of $\mathbf{L}^{1}$ and $\mathbf{L}^{3}$ extract $\mathrm{CuSO}_{4}$ and $\mathrm{CuCl}_{2}$ from water into chloroform with high selectivity over the corresponding $\mathrm{Co}(\mathrm{II}), \mathrm{Ni}(\mathrm{II})$ and $\mathrm{Zn}$ (II) salts.
\end{abstract}

Keywords: hydrometallurgy; anion recognition; copper(II) complexes; ditopic ligands; solvent extraction experiments; urea moiety

\section{Introduction}

Modern hydrometallurgical processes employ solvent extraction to separate and concentrate targeted metals after the dissolution of ores in aqueous media. ${ }^{1,2}$ Frequently the extractants generate anionic ligands that form hydrophobic charge-neutral complexes with the targeted metal ion. ${ }^{3}$ Alternatively, the migration of the metal ion to the organic phase may be aided by the simultaneous recognition of attendant anions, transferring a metal salt. For instance, extraction of $\mathrm{CuCl}_{2}$ and $\mathrm{ZnCl}_{2}$ can be achieved by using appropriate extractants that form charge neutral complexes of the form $\left[\mathrm{CuCl}_{2} \mathrm{~L}_{2}\right]$ or $\left[\mathrm{Zn}_{2} \mathrm{Cl}_{4} \mathrm{~L}_{2}\right]$, ${ }^{4,5}$ where $\mathrm{L}$ represents the extractant. Application of this strategy to the extraction of metal sulfates is more challenging due to the weak coordinating ability of this anion and its high hydration energy. ${ }^{6}$ This makes it energetically less favourable to transfer sulfate into a hydrophobic medium than monoanions such as chloride or nitrate (the Hofmeister 
bias). ${ }^{7}$ Consequently, the extraction of metal sulfates from aqueous solutions requires developing alternative strategies.

The most successful approach to achieve selective extraction of sulfate salts relies on the use of ditopic receptors that possess two well-defined binding sites for the metal cation and the sulfate anion. Metal salt recognition may occur either independently or through cooperative binding involving the coordination of the anion to the metal ion and the synergistic interaction of the anion with the ditopic ligand through hydrogen bonds. Among the anion recognition units incorporated into ditopic metal salt receptors are amides, ${ }^{8}$ ammonium, ${ }^{9}$ guanidinium, ${ }^{10}$ pyrrol, ${ }^{11}$ urea $^{12}$ and thiourea ${ }^{13}$ groups.

In previous work we showed that the binding of an anion to a $\mathrm{Cu}(\mathrm{II})$ complex of the ditopic receptor $\mathbf{L}^{\mathbf{1}}$ is cooperative, involving both coordination of the anion to the copper ion and hydrogen bonding with the urea unit of the ligand. ${ }^{14}$ The binding of $\mathrm{SO}_{4}{ }^{2-}$ generates a charge-neutral complex that could be exploited for the extraction of $\mathrm{CuSO}_{4}$. Herein we report an analogue $\mathbf{L}^{2}$ with a hydrophobic hexyl chain replacing the nitro group and two new ditopic ligands, $\mathbf{L}^{3}$ and $\mathbf{L}^{4}$, which are based on a cyclen unit which is expected to increase the stability of the corresponding $\mathrm{Cu}$ (II) complexes as the stability constant reported for $[\mathrm{Cu}(\mathrm{cyclen})]^{2+}(\log$ $\left.K_{11}=23.4\right)^{15,16}$ is ten orders of magnitude higher than that for $[\mathrm{Cu}(\mathrm{dpa})]^{2+}(\mathrm{dpa}=\operatorname{di}(2$-picolyl $)$ amine, $\log$ $\left.K_{11}=13.8\right) .{ }^{17}$ Furthermore, $\mathrm{Cu}(\mathrm{II})$ complexes with cyclen derivatives generally form complexes with square pyramidal coordination environment, where the basal plane is defined by the four nitrogen atoms of the macrocycle and the apical position is occupied by an additional ligand. ${ }^{18}$ This feature should provide easy access for a coordinating anion which is then well placed to interact with the urea anion-acceptor. The ability of $\left[\mathrm{CuL}^{3}\right]^{2+}$ to bind anions through cooperative interactions, investigated using spectrophotometric titrations, and solvent extraction studies to assess the potential of $\mathbf{L}^{2}$ and $\mathbf{L}^{4}$ to extract different $\mathrm{Cu}$ (II) salts are reported below.

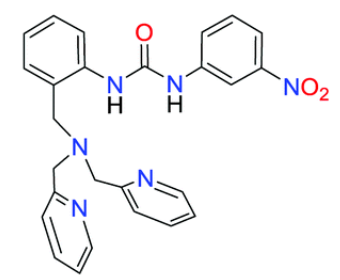

$L^{1}$

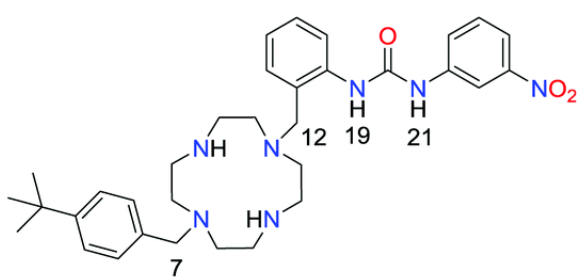

$\mathrm{L}^{3}$

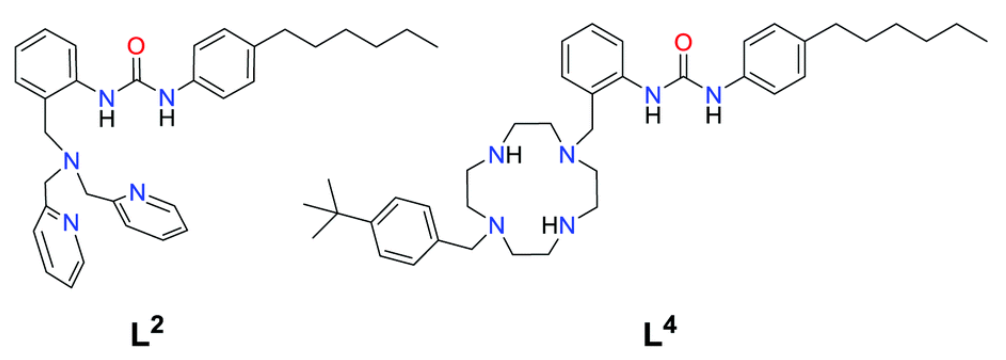

Scheme 1. Structures of the ligands $\mathrm{L}^{1-4}$ investigated in this work.

\section{Results and discussion}

\section{$\underline{\text { Synthesis of the ligands }}$}

Full experimental details are provided in the ESI. $\dagger \mathbf{L}^{2}$ was obtained using a procedure (Scheme 2) similar to that for $\mathbf{L}^{1}{ }^{14}$ The syntheses of $\mathbf{L}^{\mathbf{3}}$ and $\mathbf{L}^{\mathbf{4}}$ involved the monoalkylation of diBoc-cyclen ${ }^{19}$ (5) with either $\mathbf{3 a}$ or 
$\mathbf{3 b}$ using a fivefold excess of $\mathbf{5}$ to avoid the formation of the dialkylated product. Reaction of $\mathbf{6 a}$ and $\mathbf{6 b}$ with 1-(bromomethyl)-4-(tert-butyl)benzene gave $\mathbf{7 a}$ and $\mathbf{7 b}$ in moderate yields $(\sim 54 \%)$ which were deprotected quantitatively using a 1:1 mixture of chloroform and trifluoroacetic acid (Scheme 3).

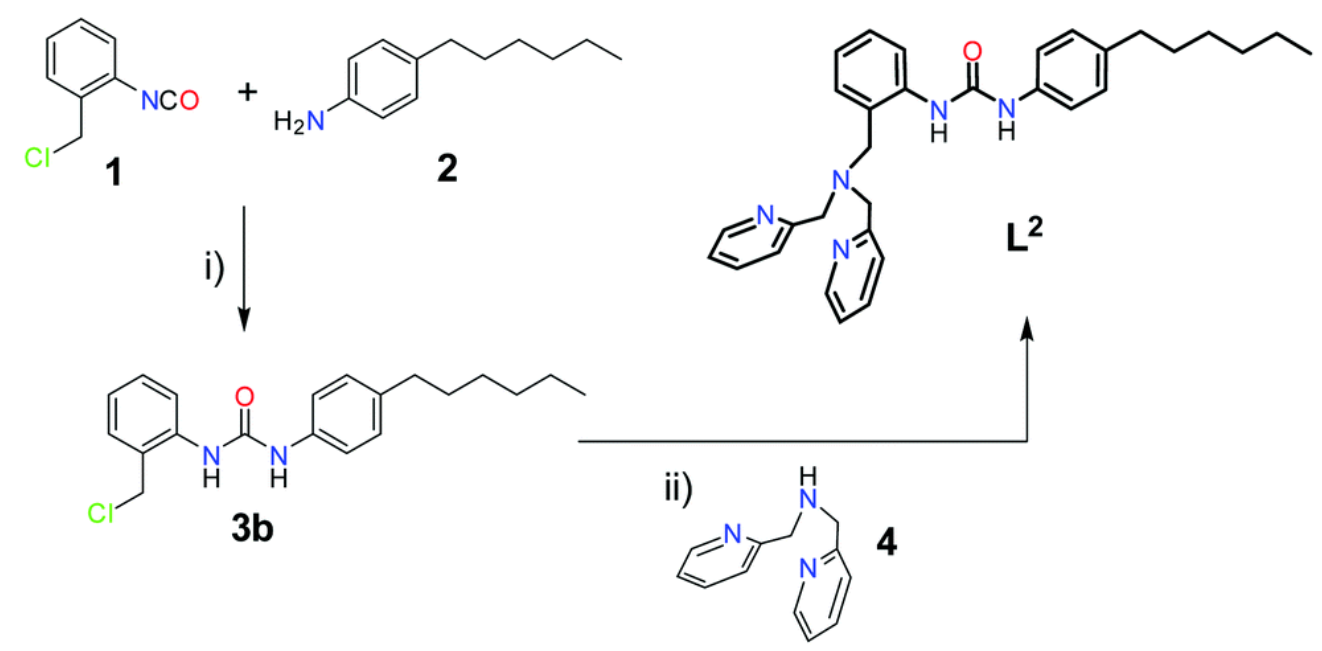

Scheme 2. Synthesis of $\mathrm{L}^{2}$. Reagents and conditions: (i) $\mathrm{Et}_{2} \mathrm{O}$, r.t., 48 h; (ii) $\mathrm{CH}_{3} \mathrm{CN}$, dipea, $\mathrm{KI}$ (cat.), $\Delta, 72 \mathrm{~h}$.

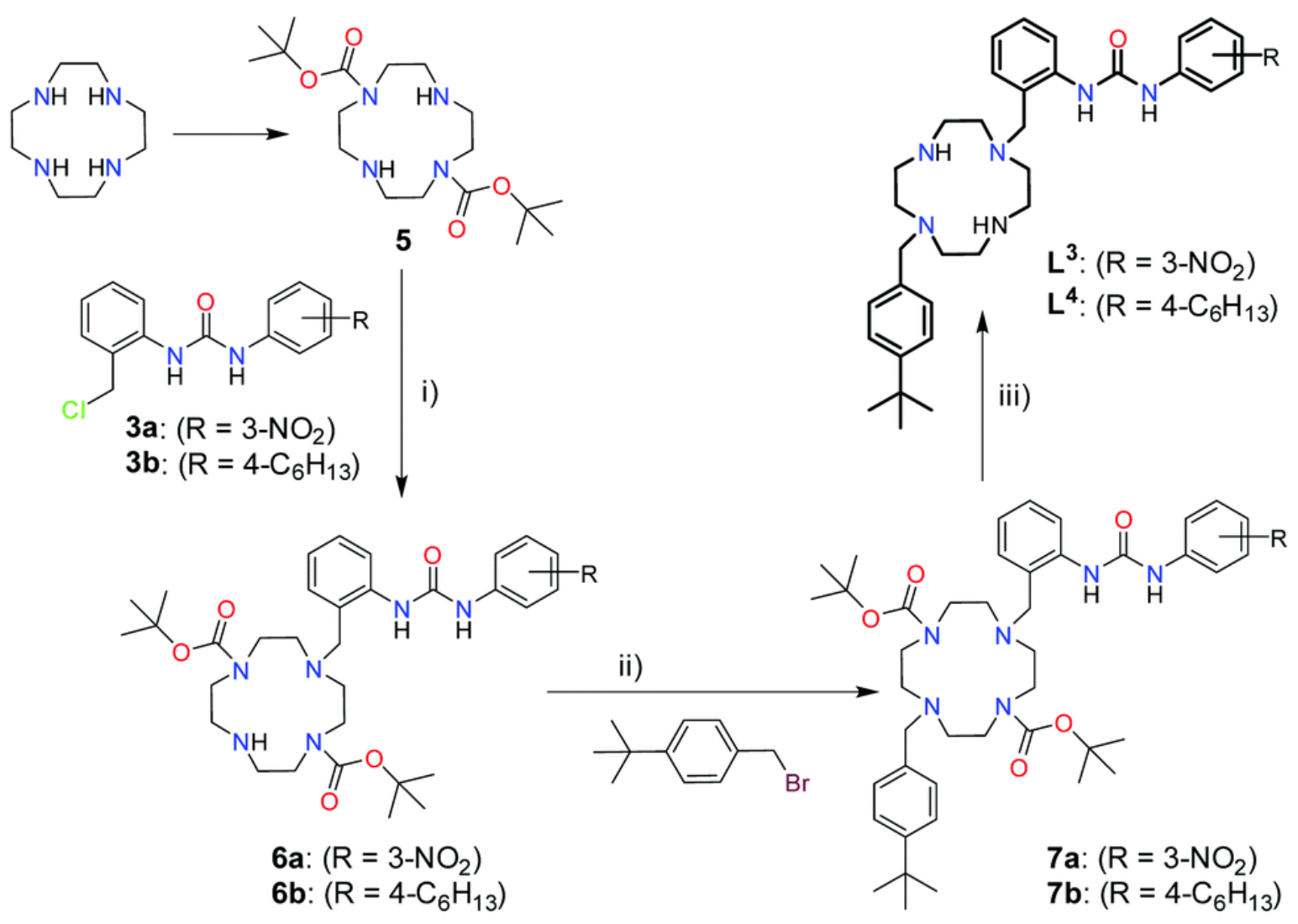

Scheme 3. Synthesis of $\mathrm{L}^{3}$ and $\mathrm{L}^{4}$. Reagents and conditions: (i) $\mathrm{CH}_{3} \mathrm{CN}, \mathrm{K}_{2} \mathrm{CO}_{3}$, r.t., 16 h; (ii) $\mathrm{CH}_{3} \mathrm{CN}$, dipea, $\mathrm{KI}$ (cat.), $\Delta, 16 \mathrm{~h}$; (iii) $\mathrm{CHCl}_{3}: \mathrm{tfa}(1: 1)$, r.t., $16 \mathrm{~h}$. 
The structure of $\mathbf{L}^{3}$ was confirmed by X-ray diffraction (Fig. 1). The conformation of the macrocycle in the solid state is defined by the formation of intramolecular hydrogen bonds between the urea $\mathrm{NH}$ groups and two nitrogen atoms of the macrocyclic fragment $\left[\mathrm{N}(3) \cdots \mathrm{N}(4), 2.900(2) \AA, \mathrm{N}(3)-\mathrm{H}(3 \mathrm{~N}) \cdots \mathrm{N}(4) 140(2)^{\circ}\right.$; $\left[\mathrm{N}(3) \cdots \mathrm{N}(5), 3.379(2) \AA, \mathrm{N}(3)-\mathrm{H}(3 \mathrm{~N}) \cdots \mathrm{N}(5) 144(1)^{\circ} ; \mathrm{N}(2) \cdots \mathrm{N}(5), 2.902(2) \AA, \mathrm{N}(2)-\mathrm{H}(2 \mathrm{~N}) \cdots \mathrm{N}(5) 172(2)\right]^{\circ}$. An additional intramolecular hydrogen bond involves the two secondary amine nitrogen atoms of the cyclen moiety $\left[\mathrm{N}(5) \cdots \mathrm{N}(6), 3.441(2) \AA, \mathrm{N}(5)-\mathrm{H}(5 \mathrm{~N}) \cdots \mathrm{N}(6) 171(1)^{\circ}\right]$. The 12-membered macrocycle adopts a square [3333] conformation in which the ligand is predisposed to bind metal ions. ${ }^{20}$

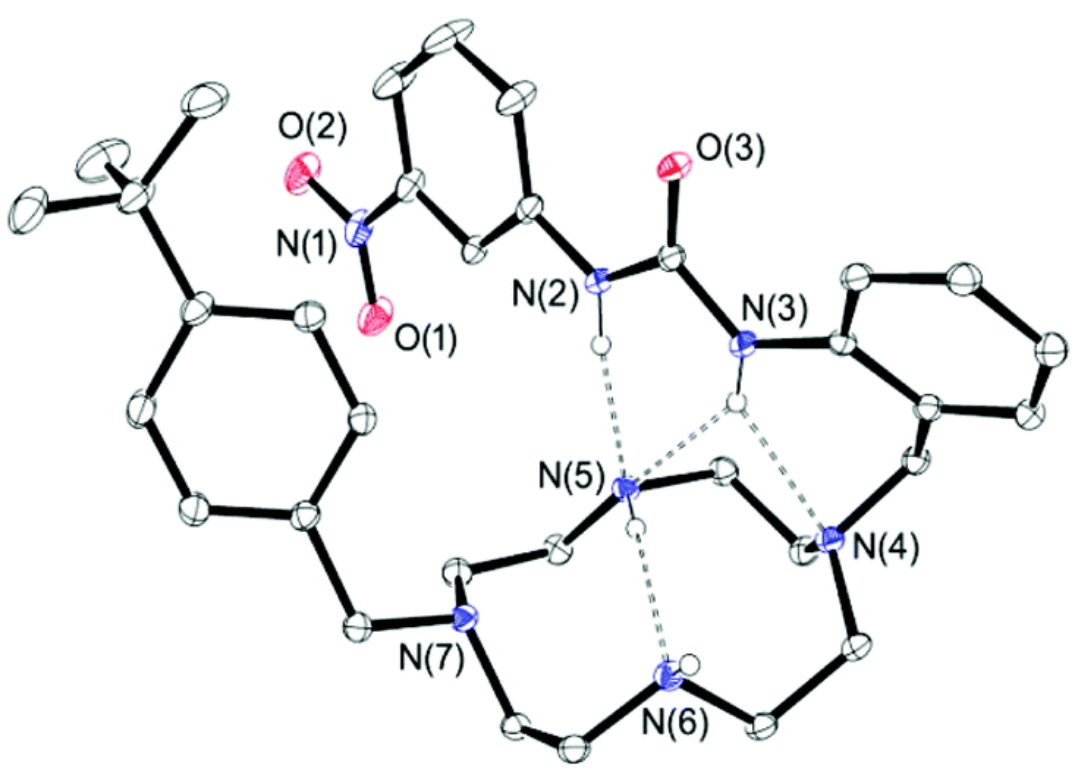

Fig. 1. View of the X-ray structure of $\mathrm{L}^{3}$. Hydrogen atoms bonded to carbon are omitted for clarity. The thermal parameters in this and Fig. 2-4 are plotted at the 30\% probability level.

$\underline{\text { Synthesis and characterization of the metal complexes }}$

Prior to the isolation of solid complexes, the coordination of $\mathbf{L}^{3}$ to $\mathbf{C u}(\mathrm{II})$ was investigated using spectrophotometric titrations in acetonitrile solution (Fig. S1, ESI $\dagger$ ). The absorption spectrum of $\mathbf{L}^{3}$ shows an intense band at $261 \mathrm{~nm}\left(\varepsilon=40363 \mathrm{M}^{-1} \mathrm{~cm}^{-1}\right)$ characteristic of the diphenylurea chromophore ${ }^{21}$ together with a weak absorption at $350 \mathrm{~nm}\left(\varepsilon=1900 \mathrm{M}^{-1} \mathrm{~cm}^{-1}\right)$ attributed to the $-\mathrm{NO}_{2}$ group in meta position with respect to the urea unit. Addition of $\mathrm{Cu}(\mathrm{OTf})_{2}$ is accompanied by hypsochromic shifts of the two absorption bands. The titration profile shows a single inflection point and three isosbestic points at 210, 252 and $280 \mathrm{~nm}$ that are consistent with a $1: 1$ stoichiometry (Fig. S1, ESI†).

Reaction of $\mathbf{L}^{3}$ with one equivalent of $\mathrm{MCl}_{2}$ or hydrated $\mathrm{M}\left(\mathrm{NO}_{3}\right)_{2}, \mathrm{M}\left(\mathrm{ClO}_{4}\right)_{2}$ and $\mathrm{M}\left(\mathrm{SO}_{4}\right)(\mathrm{M}=\mathrm{Cu}$ or $\mathrm{Zn})$ in methanol at room temperature yielded the desired complexes isolated as the corresponding chloride, perchlorate, nitrate or sulfate salts in $59-88 \%$ yields.

Slow evaporation of solutions of $\left[\mathrm{CuL}^{3}\left(\mathrm{SO}_{4}\right)\right] \cdot 1.5 \mathrm{H}_{2} \mathrm{O}$ and $\left[\mathrm{ZnL}^{3}\left(\mathrm{NO}_{3}\right)_{2}\right] \cdot \mathrm{CHCl}_{3}$ in chloroform/methanol or acetonitrile/methanol afforded single crystals suitable for X-ray structure determination of formula $\left[\mathrm{CuL}^{3}\left(\mathrm{SO}_{4}\right)\right] \cdot \mathrm{MeOH}$ and $\left[\mathrm{ZnL}^{3}\left(\mathrm{NO}_{3}\right)\right] \mathrm{NO}_{3} \cdot 0.75 \mathrm{MeOH}$, respectively. Structures are shown in Fig. 2 and 3, and bond distances in the inner coordination spheres are listed in Table 1. The coordination polyhedron around the $\mathrm{Cu}(\mathrm{II})$ ion in $\left[\mathrm{CuL}^{3}\left(\mathrm{SO}_{4}\right)\right] \cdot \mathrm{MeOH}$ can be described as a square pyramid, the donor atoms of the cyclen fragment $[\mathrm{N}(4), \mathrm{N}(5), \mathrm{N}(6)$ and $\mathrm{N}(7)]$ defining the basal plane and one of the oxygen atoms of the sulfate anion $[\mathrm{O}(4)]$ occupying the apical position (Fig. 2). The metal ion is located $0.55 \AA$ above the basal 
plane (mean deviation from planarity: $0.03 \AA$ ). The cis angles of this plane, ranging between $84.1^{\circ}$ and $86.8^{\circ}$, are slightly smaller than $90^{\circ}$ due to the displacement of the metal ion from the basal plane. For the same reason the $\mathrm{O}(4)-\mathrm{Cu}(1)-\mathrm{N}$ angles deviate up to $22^{\circ}$ from $90^{\circ}$ (Table S1, ESI $\dagger$ ), while the trans angles fall in the range $146.1-150.8^{\circ}$. The index of trigonality $\tau$ amounts to 0.08 , which is in agreement with a square pyramidal geometry. ${ }^{22}$ The distances between the heteroatoms of the cyclen subunit and the $\mathrm{Cu}$ (II) ion are similar to those reported for other five-coordinated $\mathrm{Cu}(\mathrm{II})$ complexes containing cyclen. ${ }^{23}$ The four fivemembered chelate rings formed upon coordination of the cyclen fragment adopt identical conformations, which results in the $(\delta \delta \delta \delta)$ [or $(\lambda \lambda \lambda \lambda)$ ] conformation of the macrocyclic unit often observed in the solid state for metal complexes with cyclen-based ligands. ${ }^{24}$

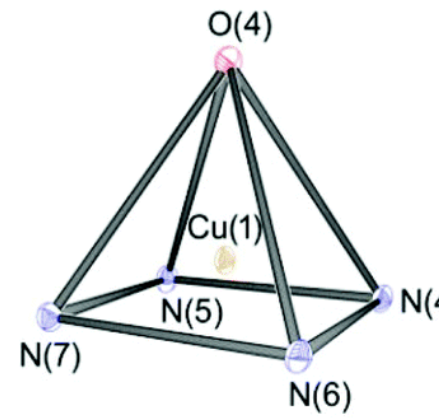

$\mathrm{N}(4)$

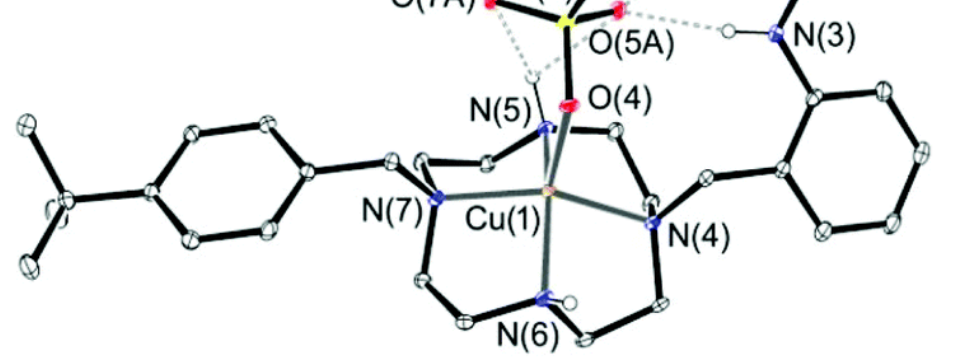

Fig. 2. The X-ray structure of $\left[\mathrm{CuL}^{3}\left(\mathrm{SO}_{4}\right)\right]$. Hydrogen atoms bonded to carbon atoms are omitted for clarity. The inset shows a representation of the square pyramidal coordination polyhedron.

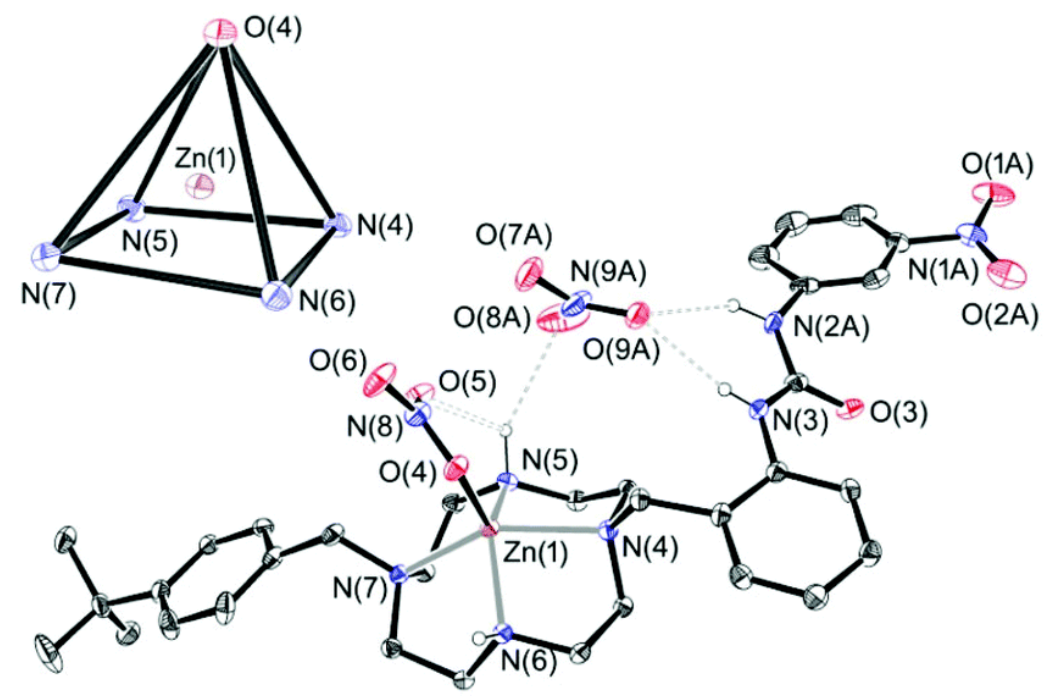

Fig. 3. The X-ray structure of $\left[\mathrm{ZnL}^{3}\left(\mathrm{NO}_{3}\right)\right]\left(\mathrm{NO}_{3}\right)$. Hydrogen atoms bonded to carbon atoms are omitted for clarity. The inset shows a representation of the square pyramidal coordination polyhedron. The uncoordinated nitrate ion and the distal part of the urea moiety show positional disorder with occupation factor of $0.613(8)$ for atoms labelled with A. 
Table 1. Bond distances $(\AA)$ of the metal coordination spheres in $\left[\mathrm{CuL}^{3}\left(\mathrm{SO}_{4}\right)\right] \cdot \mathrm{MeOH},\left[\mathrm{ZnL} \mathbf{L}^{3}\left(\mathrm{NO}_{3}\right)\right]\left(\mathrm{NO}_{3}\right) \cdot 0.75 \mathrm{MeOH}$ and $\left[\mathrm{CuL}^{\mathbf{1}}\left(\mu-\mathrm{SO}_{4}\right)\right]_{2} \cdot \mathrm{C}_{6} \mathrm{H}_{6} \mathrm{~N}_{2} \mathrm{O}_{2}$

\begin{tabular}{llll}
\hline & {$\left[\mathrm{CuL}^{3}\left(\mathrm{SO}_{4}\right)\right]$} & {$\left[\mathrm{ZnL}^{3}\left(\mathrm{NO}_{3}\right)\right] \mathrm{NO}_{3}$} & {$\left[\mathrm{CuL}^{1}\left(\mu-\mathrm{SO}_{4}\right)\right]_{2}{ }^{a}$} \\
\hline $\mathrm{M}(1)-\mathrm{N}(3)$ & & & $3.007(1)$ \\
$\mathrm{M}(1)-\mathrm{N}(4)$ & $2.083(2)$ & $2.228(2)$ & $2.032(2)$ \\
$\mathrm{M}(1)-\mathrm{N}(5)$ & $2.001(2)$ & $2.088(3)$ & $1.998(2)$ \\
$\mathrm{M}(1)-\mathrm{N}(6)$ & $2.019(2)$ & $2.093(2)$ & $1.980(2)$ \\
$\mathrm{M}(1)-\mathrm{N}(7)$ & $2.071(2)$ & $2.188(3)$ & \\
$\mathrm{M}(1)-\mathrm{O}(4)$ & $2.150(2)$ & $1.989(2)$ & $1.939(1)$ \\
$\mathrm{M}(1)-\mathrm{O}(7) \# 1$ & & & $2.327(1)$ \\
\hline
\end{tabular}

${ }^{a}$ Symmetry transformations used to generate equivalent atoms: $\# 1-x+1,-y+1,-z+1$.

The coordinated sulfate anion in $\left[\mathrm{CuL}^{3}\left(\mathrm{SO}_{4}\right)\right] \cdot \mathrm{MeOH}$ forms three comparably strong hydrogen bonds with the $\mathrm{NH}$ groups of the urea, $\mathrm{N}(2)$ and $\mathrm{N}(3)$. Additional weak hydrogen bonds involve the oxygen atoms of the sulfate group $\mathrm{O}(5 \mathrm{~A})$ and $\mathrm{O}(7 \mathrm{~A})$ and the secondary amine nitrogen atom $\mathrm{N}(5)$ of the cyclen unit (Table 2).

Table 2. Some intramolecular hydrogen bonds in $\left[\mathrm{CuL}^{3}\left(\mathrm{SO}_{4}\right)\right] \cdot \mathrm{MeOH},\left[\mathrm{ZnL}^{3}\left(\mathrm{NO}_{3}\right)\right]\left(\mathrm{NO}_{3}\right) \cdot 0.75 \mathrm{MeOH}$ and $\left[\mathrm{CuL}^{\mathbf{1}}\left(\mu-\mathrm{SO}_{4}\right)\right]_{2} \cdot \mathrm{C}_{6} \mathrm{H}_{6} \mathrm{~N}_{2} \mathrm{O}_{2}$

\begin{tabular}{lllll}
\hline$\left[\mathrm{CuL}^{3}\left(\mathrm{SO}_{4}\right)\right]^{a}$ & $d(\mathrm{D} \cdots \mathrm{A}) / \AA$ & $d(\mathrm{H} \cdots \mathrm{A}) / \AA$ & $\mathrm{D}-\mathrm{H} \cdots \mathrm{A}^{\circ}$ & $\mathrm{S}(2)-\mathrm{O} \cdots \mathrm{H} /{ }^{\circ}$ \\
\hline $\mathrm{N}(2)-\mathrm{H}(2 \mathrm{~N}) \cdots \mathrm{O}(6 \mathrm{~A})$ & $3.117(7)$ & 2.29 & 155.8 & 97.6 \\
$\mathrm{~N}(2)-\mathrm{H}(2 \mathrm{~N}) \cdots \mathrm{O}(5 \mathrm{~A})$ & $3.121(6)$ & 2.38 & 142.0 & 93.0 \\
$\mathrm{~N}(3)-\mathrm{H}(3 \mathrm{~N}) \cdots \mathrm{O}(5 \mathrm{~A})$ & $2.917(4)$ & 2.08 & 159.7 & 128.7 \\
$\mathrm{~N}(5)-\mathrm{H}(5 \mathrm{~N}) \cdots \mathrm{O}(5 \mathrm{~A})$ & $2.961(7)$ & 2.39 & 115.5 & 89.0 \\
$\mathrm{~N}(5)-\mathrm{H}(5 \mathrm{~N}) \cdots \mathrm{O}(7 \mathrm{~A}) \# 1$ & $2.968(5)$ & 2.27 & 126.1 & 79.0 \\
\hline$\left[\mathrm{Zn} \mathbf{L}^{3}\left(\mathrm{NO}_{3}\right)\right]\left(\mathrm{NO}_{3}\right)^{b}$ & $d(\mathrm{D} \cdots \mathrm{A}) / \AA$ & $d(\mathrm{H} \cdots \mathrm{A}) / \AA$ & $\mathrm{D}-\mathrm{H} \cdots \mathrm{A} /{ }^{\circ}$ & $\mathrm{N}(9 \mathrm{~A})-\mathrm{O} \cdots \mathrm{H} /{ }^{\circ}$ \\
\hline $\mathrm{N}(2 \mathrm{~A})-\mathrm{H}(2 \mathrm{~A}) \cdots \mathrm{O}(9 \mathrm{~A})$ & $3.09(4)$ & $2.13(11)$ & $149(7)$ & 131.9 \\
$\mathrm{~N}(3)-\mathrm{H}(3 \mathrm{~N}) \cdots \mathrm{O}(9 \mathrm{~A})$ & $2.87(2)$ & $2.08(6)$ & $161(5)$ & 153.3 \\
$\mathrm{~N}(5)-\mathrm{H}(5 \mathrm{~N}) \cdots \mathrm{O}(5)$ & $2.978(4)$ & $2.47(5)$ & $120(4)$ & 116.4 \\
$\mathrm{~N}(5)-\mathrm{H}(5 \mathrm{~N}) \cdots \mathrm{O}(8 \mathrm{~A}) \# 1$ & $3.351(13)$ & $2.62(5)$ & $148(9)$ & \\
\hline$\left[\mathrm{CuL} \mathbf{L}^{\mathbf{1}}\left(\mu-\mathrm{SO} \mathrm{H}_{4}\right)\right]_{2}$ & $d(\mathrm{D} \cdots \mathrm{A}) / \AA$ & $d(\mathrm{H} \cdots \mathrm{A}) / \AA$ & $\mathrm{D}-\mathrm{H} \cdots \mathrm{A} /{ }^{\circ}$ & $\mathrm{S}(1)-\mathrm{O} \cdots \mathrm{H} /{ }^{\circ}$ \\
\hline $\mathrm{N}(2)-\mathrm{H}(2 \mathrm{~N}) \cdots \mathrm{O}(6)$ & $2.959(2)$ & $2.14(2)$ & $172(2)$ & 102.6 \\
$\mathrm{~N}(3)-\mathrm{H}(3 \mathrm{~N}) \cdots \mathrm{O}(5)$ & $2.790(2)$ & $1.99(2)$ & $169(2)$ & 102.2 \\
\hline
\end{tabular}

${ }^{a}$ Symmetry transformations used to generate equivalent atoms: $\# 1-x,-y,-z .{ }^{b}$ Symmetry transformations used to generate equivalent atoms: \#1 $x+3 / 2, y+1 / 2,-z+3 / 2 \# 2-x+3 / 2,-y+3 / 2,-z+1 \# 3-x+3 / 2, y-1 / 2$, $-z+3 / 2 \# 4 x+1 / 2, y-1 / 2, z+1$.

Crystals of $\left[\mathrm{ZnL}^{3}\left(\mathrm{NO}_{3}\right)\right] \mathrm{NO}_{3} \cdot 0.75 \mathrm{MeOH}$ contain a five coordinate $\mathrm{Zn}$ (II) ion directly bound to the four nitrogen atoms of the macrocycle and an oxygen atom of a coordinated nitrate anion (Fig. 3). The metal coordination environment can be best described as square-pyramidal $(\tau=0.15)$, with the basal plane of the pyramid (mean deviation from planarity: $0.057 \AA$ ) being defined by the four donor atoms of the cyclen fragment $[\mathrm{N}(4), \mathrm{N}(5), \mathrm{N}(6)$ and $\mathrm{N}(7)]$; the apical position is occupied by an oxygen atom of the coordinated nitrate anion $[\mathrm{O}(4)]$. The $\mathrm{Zn}(1)-\mathrm{O}(4)$ distance $(1.989(2) \AA)$ is $c a .0 .1-0.2 \AA$ shorter than those between the $\mathrm{Zn}$ (II) ion and the nitrogen atoms of the basal plane (Table 1). These bond distances are similar to the ones 
reported for other five-coordinated $\mathrm{Zn}$ (II) complexes containing cyclen. ${ }^{25}$ The metal ion is located $0.76 \AA$ above the basal plane, resulting in cisangles in the range $81.86-84.00^{\circ}$, and angles defined by the $\mathrm{Zn}(1)-\mathrm{O}(4)$ vector and the donor atoms of the basal plane of 106.1-120.0 $0^{\circ}$

Unlike in $\left[\mathrm{CuL}^{3}\left(\mathrm{SO}_{4}\right)\right]$, the coordinated anion does not interact with the urea group in $\left[\mathrm{Zn} \mathbf{L}^{3}\left(\mathrm{NO}_{3}\right)\right]\left(\mathrm{NO}_{3}\right)$. Instead, the coordinated nitrate anion establishes a weak intramolecular hydrogen-bonding interaction with the $\mathrm{N}(5)-\mathrm{H}(5 \mathrm{~N})$ group of the cyclen subunit (Table 2). The uncoordinated nitrate anion forms an

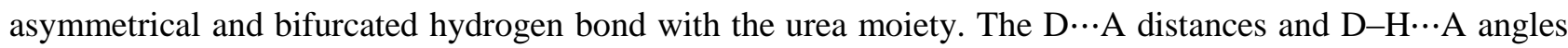
characterizing this interaction point to hydrogen bonds with a moderate strength (Table 2). The N(9A)$\mathrm{O}(9 \mathrm{~A}) \cdots \mathrm{H}(2 \mathrm{~A})$ and $\mathrm{N}(9 \mathrm{~A})-\mathrm{O}(9 \mathrm{~A}) \cdots \mathrm{H}(3 \mathrm{~N})$ angles $\left(126.8^{\circ}\right.$ and $149.3^{\circ}$, respectively) are relatively close to the ideal value of $115 \pm 10^{\circ} .^{26}$

In previous work we reported the X-ray structure of the blue mononuclear complex $\left[\mathrm{CuL}^{\mathbf{1}}\left(\mathrm{SO}_{4}\right)\left(\mathrm{H}_{2} \mathrm{O}\right)\right]{ }^{14}$ which crystallised from an aqueous solution. The same solution also provided green crystals which contain the dimeric, centrosymmetric and charge-neutral $\left[\mathrm{CuL}^{\mathbf{1}}\left(\mu-\mathrm{SO}_{4}\right)\right]_{2}$ entity and a molecule of 3-nitroaniline, presumably arising from the hydrolysis of the urea unit (Fig. 4). The metal coordination environment is approximately square pyramidal, where the basal plane is defined by the three donor atoms of the dpa unit and an oxygen atom of the coordinated sulfate anion [O(4)]. The oxygen atom of a second sulfate anion $[\mathrm{O}(7)]$ coordinates at the apical position. The $\mathrm{Cu}(1)-\mathrm{O}(7)$ distance $(2.327(1) \AA)$ is considerably longer than those involving donor atoms of the basal plane (1.94-2.03 $\AA$, Table 1). The nitrogen atom of the urea unit $\mathrm{N}(3)$ provides a weak interaction with the $\mathrm{Cu}(\mathrm{II})$ ion $(\mathrm{Cu}(1)-\mathrm{N}(3)=3.007(1) \AA)$, as observed for $\left[\mathrm{CuL}^{\mathbf{1}}\left(\mathrm{SO}_{4}\right)\left(\mathrm{H}_{2} \mathrm{O}\right)\right]$. The two sulfate anions act as $\eta_{1}: \eta_{1}: \mu_{2}$ bridging ligands, a coordination mode observed previously in different binuclear $\mathrm{Cu}(\mathrm{II})$ complexes. ${ }^{27,28}$ The intramolecular $\mathrm{Cu}(1) \cdots \mathrm{Cu}\left(1^{\prime}\right)$ distance is 4.3914(4) A.

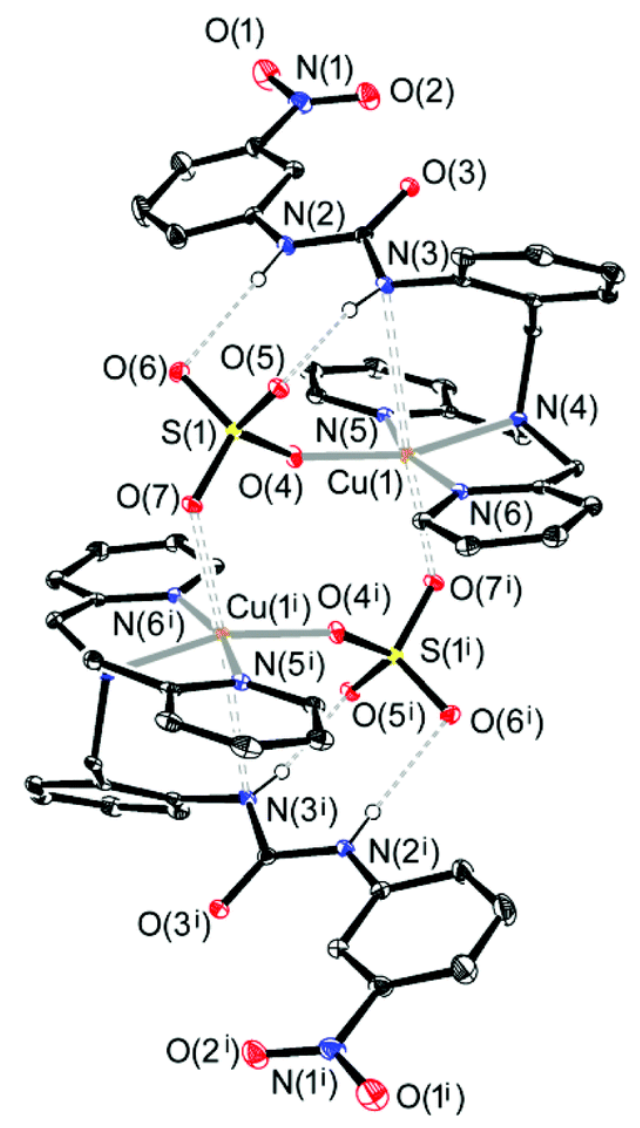

Fig. 4. View of the X-ray structure of $\left[\mathrm{CuL}^{\mathbf{1}}\left(\mu-\mathrm{SO}_{4}\right)\right]_{2}$. Hydrogen atoms bonded to carbon atoms are omitted for clarity. 
The structural features of $\left[\mathrm{CuL}^{\mathbf{1}}\left(\mu-\mathrm{SO}_{4}\right)\right]_{2}$ (Table 2) point to stronger and more directional interactions of the sulfate anion with the urea group than in $\left[\mathrm{CuL}^{3}\left(\mathrm{SO}_{4}\right)\right]$. Thus, the two $\mathrm{N}-\mathrm{H} \cdots \mathrm{O}$ contacts in $\left[\mathrm{CuL}^{\mathbf{1}}(\mu-\right.$ $\left.\left.\mathrm{SO}_{4}\right)\right]_{2}$ show similar distances and angles and the $\mathrm{S}(1)-\mathrm{O}(6)-\mathrm{H}(2 \mathrm{~N})$ and $\mathrm{S}(1)-\mathrm{O}(5)-\mathrm{H}(3 \mathrm{~N})$ angles are close to the ideal value $\left(122 \pm 12^{\circ}\right) .{ }^{29} \mathrm{In}\left[\mathrm{CuL}^{3}\left(\mathrm{SO}_{4}\right)\right]$ the $\mathrm{S}(1)-\mathrm{O}(6) \cdots \mathrm{H}(2 \mathrm{~N})$ angle $\left(97.6^{\circ}\right)$ deviates considerably from the ideal value, most likely as a consequence of the simultaneous binding to the $\mathrm{N}-\mathrm{H}$ groups of the cyclen moiety.

\section{NMR studies}

The ${ }^{1} \mathrm{H}$ NMR spectrum of $\left[\mathrm{ZnL}^{3}\right]\left(\mathrm{ClO}_{4}\right)_{2}$ shows signals at 9.36 and $8.13 \mathrm{ppm}$ due to the urea protons $\mathrm{H} 19$ and H21 (Fig. 5, see Scheme 1 for labelling). The chemical shifts in the free receptor are very different $(8.47$ and 9.93 ppm for $\mathrm{H} 19$ and H21, respectively), which likely reflects the disruption of the intramolecular hydrogen bonds involving the urea unit upon coordination of the ligand to the metal ion (Fig. 1). In the presence of more readily coordinating anions such as $\mathrm{Cl}^{-}$or $\mathrm{NO}_{3}{ }^{-}$important changes are observed. The resonance of $\mathrm{H} 21$ experiences a strong deshielding, while that of $\mathrm{H} 19$ undergoes a slight upfield shift, reflecting the establishment of hydrogen-bonding interactions between the anion and the $\mathrm{N}-\mathrm{H}$ fragments of the urea moiety. Two sets of signals with relative intensities of $2: 3$ and $1: 3$ are observed for $\left[\mathrm{ZnL}^{3}\right]\left(\mathrm{NO}_{3}\right)_{2}$ and $\left[\mathrm{ZnL}^{3}\right] \mathrm{Cl}_{2}$, pointing to the presence of two different species in solution in slow exchange on the NMR timescale. The nature of the solvent (dmso) is important in defining these isomers $\left({ }^{1} \mathrm{H}\right.$ and ${ }^{13} \mathrm{C}$ NMR spectra recorded in $\mathrm{CD}_{3} \mathrm{CN}$ solution are in agreement with the presence of a single complex species in solution (Fig. S2, ESI + )). Thus, the two species observed in dmso solution are attributed to $\left[\mathrm{Zn} \mathbf{L}^{3} \mathrm{X}\right]^{+}$and $\left[\mathrm{ZnL}^{3}\left(\mathrm{OSMe}_{2}\right) \cdots \mathrm{X}\right]^{+}$species $\left(\mathrm{X}=\mathrm{Cl}^{-}\right.$or $\left.\mathrm{NO}_{3}{ }^{-}\right)$, in which the anion is involved in hydrogen bonding interaction with the urea unit and either coordinated or non-coordinated to the metal ion. The lower coordinating character of $\mathrm{CH}_{3} \mathrm{CN}$ favours the exclusive formation of the $\left[\mathrm{ZnL}^{3} \mathrm{X}\right]^{+}$species. The ${ }^{1} \mathrm{H}$ NMR data therefore reveal that the anions interact with the urea moiety via hydrogen bonds, but exclude the coordination of the urea nitrogen atom to the metal ion, as observed for $\left[\mathrm{ZnL}^{1}\right]\left(\mathrm{ClO}_{4}\right)_{2}{ }^{14}$ DFT calculations $(\mathrm{TPSSh} / \mathrm{TZVP})^{30}$ performed on the $\left[\mathrm{ZnL}^{3} \mathrm{Cl}\right]^{+}$system in dmso solution (IEFPCM) ${ }^{31}$ support the simultaneous binding of the anion to the metal ion and the urea unit (Fig. S3, ESI $\dagger$ ).

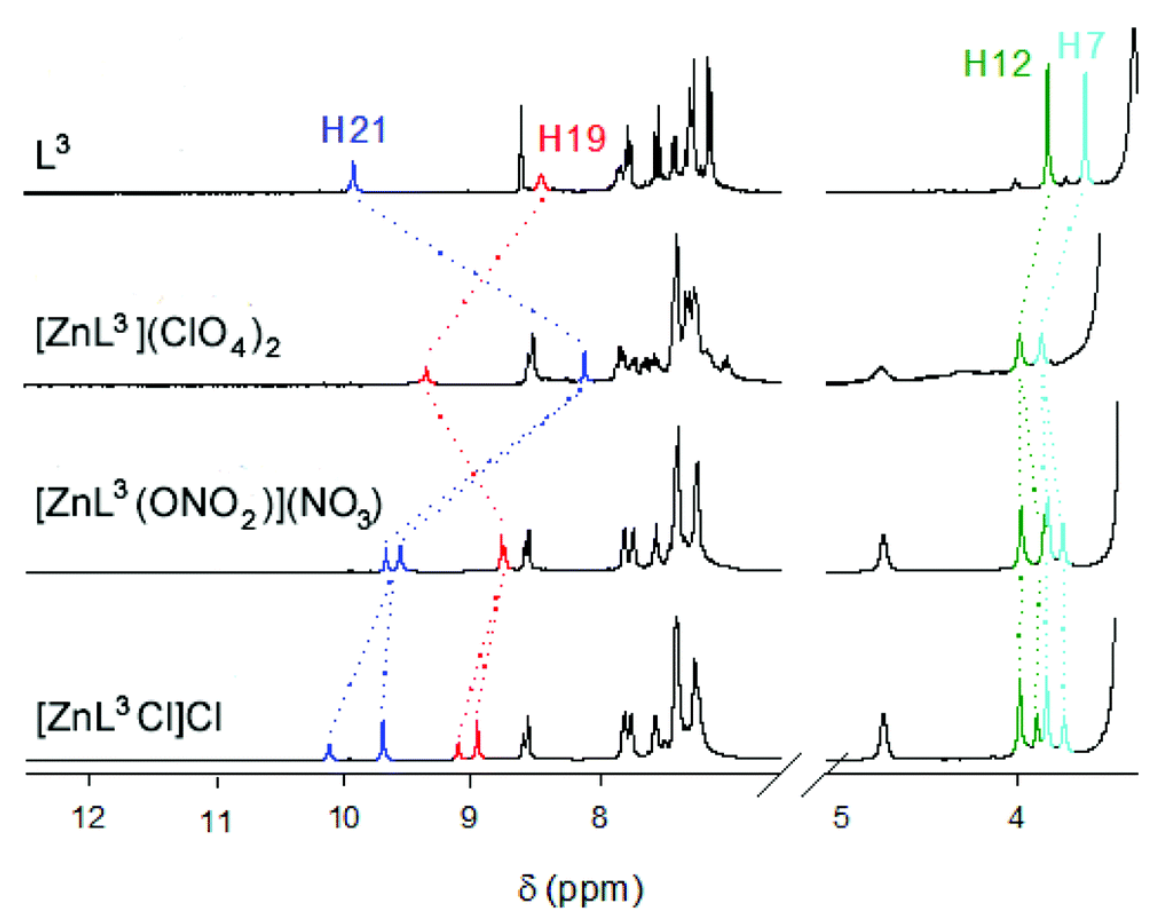

Fig. 5. ${ }^{1} \mathrm{H}$ NMR spectra $\left(300 \mathrm{MHz}, 25{ }^{\circ} \mathrm{C}\right.$, dmso- $\left.d_{6}\right)$ of $\mathbf{L}^{3}$ and its $\mathrm{Zn}$ (II) complexes. 


\section{$\underline{\text { Anion-binding studies }}$}

Before investigating the interaction of the $\mathrm{Cu}(\mathrm{II})$ complex of $\mathrm{L}^{3}$ with $\mathrm{NO}_{3}{ }^{-}, \mathrm{HSO}_{4}^{-}, \mathrm{H}_{2} \mathrm{PO}_{4}^{-}, \mathrm{NO}_{2}{ }^{-}, \mathrm{MeCO}_{2}^{-}$, $\mathrm{F}^{-}, \mathrm{Cl}^{-}$and $\mathrm{Br}^{-}$(as their tetrabutylammonium salts), the interaction of the free ligand with these anions was studied. Spectrophotometric titrations, monitored using the CT band centred on the nitro group, show that only $\mathrm{MeCO}_{2}{ }^{-}$and $\mathrm{F}^{-}$are able to compete with the solvent in forming hydrogen-bonds with the receptor (as previously observed with $\mathbf{L}^{\mathbf{1}}$ (Fig. S4, ESI $\dagger$ )). The smooth curvature of the titration profiles, which prevented an accurate calculation of the association constants, indicates that these interactions are weak. This might be attributed to the presence of intramolecular hydrogen bonds between the urea moiety and the nitrogen atoms of the ligand, which are likely stronger than those involving the urea group and the anions (Fig. 1).

The absorption spectrum of $\left[\mathrm{CuL}^{3}\left(\mathrm{OSMe}_{2}\right)\right]^{2+}$ has a broad band $(500-1200 \mathrm{~nm}$ with a maximum at 621 $\mathrm{nm}, \varepsilon=341 \mathrm{M}^{-1} \mathrm{~cm}^{-1}$ ) characteristic of $\mathrm{d}-\mathrm{d}$ transitions centred on the $\mathrm{Cu}$ (II) ion and is very similar to that in the five-coordinated cyclen complex $[\mathrm{Cu}($ cyclen $)(\mathrm{NCMe})]\left(\mathrm{W}_{6} \mathrm{O}_{19}\right) .{ }^{32 a}$ Such bands are attributed to the $\mathrm{d}_{x z}, \mathrm{~d}_{y z} \rightarrow \mathrm{d}_{x}{ }^{2}-y^{2}\left({ }^{2} \mathrm{~B}_{1} \rightarrow{ }^{2} \mathrm{E}\right)$ transition expected for a square-pyramidal geometry (Fig. 6) and DFT calculations on dmso solutions are consistent with the square pyramidal coordination provided is fulfilled by the four nitrogen atoms of the cyclen unit and an apical solvent (dmso) molecule (Fig. S3, ESI $\dagger$ ). Attempts to optimise the $\left[\mathrm{CuL}^{3}\right]^{2+}$ system with one of the nitrogen atoms of the urea unit coordinated to the metal ion resulted in its systematic expulsion from the metal's inner coordination sphere.

Solutions of $\left[\mathrm{CuL}^{3}\left(\mathrm{OSMe}_{2}\right)\right]^{2+}$ in dmso (prepared by dissolution of perchlorate salt) were titrated with stock solutions of the anions as their tetrabutylammonium salts in the same solvent $\left(10^{-3} \mathrm{M}\right.$ and $0.1 \mathrm{M}$, respectively). Anion interaction was monitored by following the variations in the $\mathrm{d}-\mathrm{d}$ band of the $\mathrm{Cu}$ (II) ion. Addition up to a 20 -fold excess of $\mathrm{NO}_{3}{ }^{-}$is accompanied by only small changes in the absorption spectrum, which indicates a very weak binding of this anion to the metal complex. In contrast, addition of $\mathrm{HSO}_{4}{ }^{-}$causes a slight red shift of the $\mathrm{d}-\mathrm{d}$ band and its intensity slightly decreases (Fig. 6a). However, a reliable association constant could not be determined given the slight curvature of the titration profile.

Addition of $\mathrm{H}_{2} \mathrm{PO}_{4}^{-}, \mathrm{NO}_{2}^{-}, \mathrm{MeCO}_{2}^{-}, \mathrm{PhCO}_{2}^{-}, \mathrm{Cl}^{-}$or $\mathrm{Br}^{-}$to solutions of $\left[\mathrm{CuL}^{3}\left(\mathrm{OSMe}_{2}\right)\right]^{2+}$ in dmso causes significant changes in the $\mathrm{d}-\mathrm{d}$ absorption band of the complex (Fig. 6, see also Fig. S5, ESI $\dagger$ ); anion addition provokes a red shift of the $\mathrm{d}-\mathrm{d}$ band of $48-98 \mathrm{~nm}$ and its intensity decreases slightly (Table 3 ), which is in agreement with the position of the dmso ligand in the spectrochemical series with respect to the employed anions. ${ }^{32 b}$ The shape of the $\mathrm{d}-\mathrm{d}$ absorption band does not change upon anion addition, which suggests that the square pyramidal coordination is retained. The titrations with $\mathrm{H}_{2} \mathrm{PO}_{4}{ }^{-}, \mathrm{NO}_{2}{ }^{-}, \mathrm{Cl}^{-}$and $\mathrm{Br}^{-}$present a single inflection point with two clear isosbestic points, consistent with the formation of $1: 1$ complexes. The equilibrium constant determined for the interaction with $\mathrm{Cl}^{-}\left(\log K_{11}=5.57(2)\right)$ is higher than that with $\mathrm{Br}^{-}\left(\log K_{11}=4.22(3)\right)$, which is in agreement with the higher stability of $\mathrm{Cu}$ (II) complexes with $\mathrm{Cl}^{-}$and the better hydrogen-bonding acceptor character of $\mathrm{Cl}^{-}$compared to $\mathrm{Br}^{-33}$ The association constants determined for the interaction of $\left[\mathrm{CuL}^{3}\left(\mathrm{OSMe}_{2}\right)\right]^{2+}$ with $\mathrm{Cl}^{-}$and $\mathrm{Br}^{-}$are lower than those obtained for $\left[\mathrm{CuL}^{1}\left(\mathrm{OSMe}_{2}\right)_{2}\right]^{2+}$ (Table 3).

The equilibrium constant $\log K_{11}$ determined for $\mathrm{NO}_{2}^{-}\left(\log K_{11}=3.65(3)\right)$ is lower than that measured previously for $\left[\mathrm{CuL}^{1}\left(\mathrm{OSMe}_{2}\right)_{2}\right]^{2+}\left(\log K_{11}=5.46(9)\right)$. In the latter the $\mathrm{NO}_{2}{ }^{-}$is coordinated to the metal ion in a bidentate fashion. However, $\left[\mathrm{CuL}^{3}\left(\mathrm{OSMe}_{2}\right)\right]^{2+}$ presents only one coordination position available for anion binding. Consequently only a monodentate coordination mode of an anion is possible, explaining weaker binding. The higher value of $\log K_{11}$ obtained for $\mathrm{H}_{2} \mathrm{PO}_{4}^{-}$in $\left[\mathrm{CuL}^{3}\left(\mathrm{OSMe}_{2}\right)\right]^{2+}$ compared to $\left[\mathrm{CuL}^{1}\left(\mathrm{OSMe}_{2}\right)_{2}\right]^{2+}$ is perhaps a consequence of a stronger interaction of this anion with the urea moiety, since in $\left[\mathrm{CuL}^{3}\left(\mathrm{OSMe}_{2}\right)\right]^{2+}$ the urea group, unlike in $\left[\mathrm{CuL}^{\mathbf{1}}\left(\mathrm{OSMe}_{2}\right)_{2}\right]^{2+}$, is not coordinated to the metal ion. 

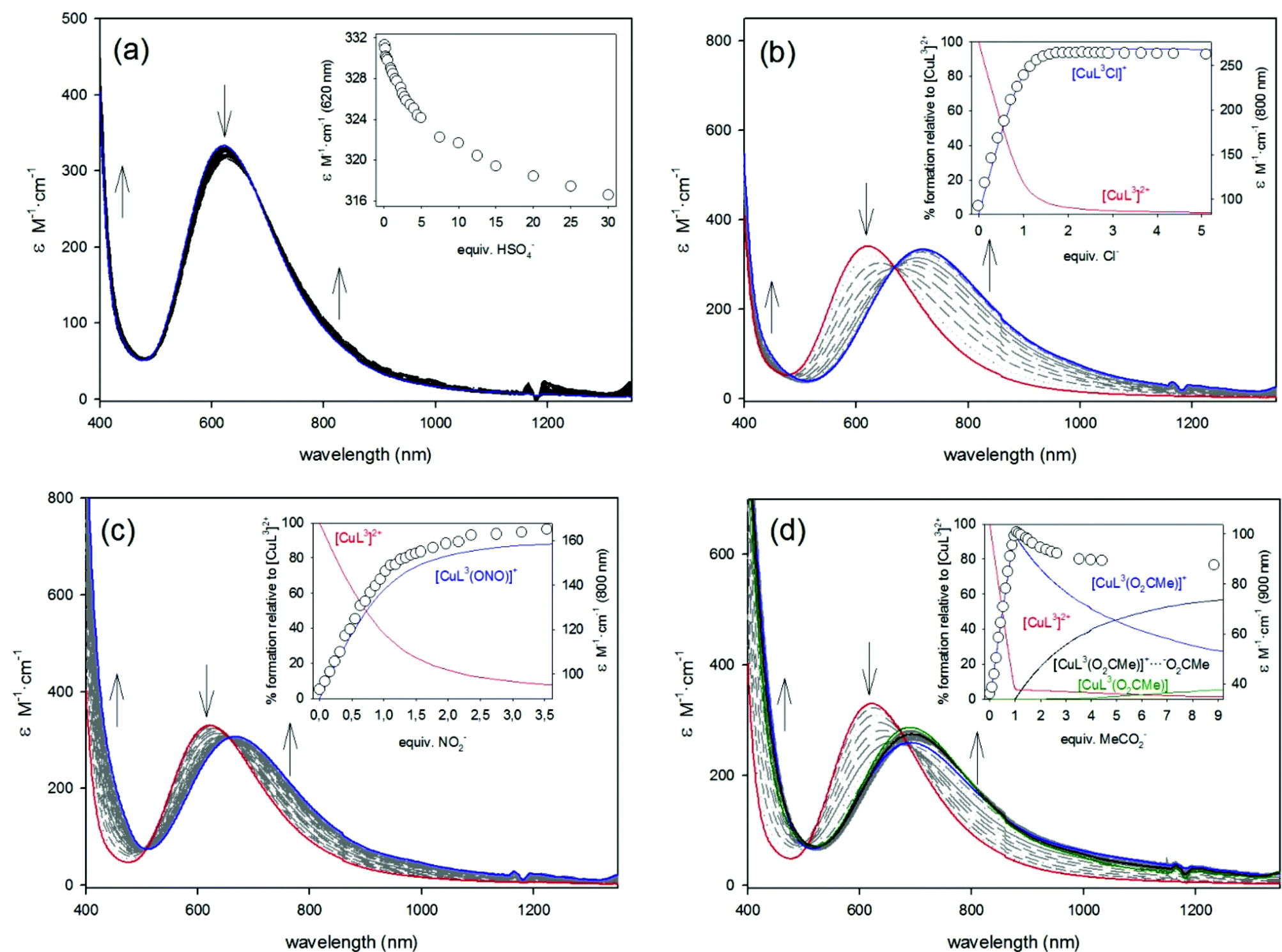

Fig. 6. UV/vis spectra recorded during the titration of $\left[\mathrm{CuL}^{3}\left(\mathrm{OSMe}_{2}\right)\right]^{2+}\left(10^{-3} \mathrm{M}\right.$ in dmso) with a standard solution $\left(0.1 \mathrm{M}\right.$ in dmso, $\left.25^{\circ} \mathrm{C}\right)$ of: $(\mathrm{a})\left[\mathrm{Bu}_{4} \mathrm{~N}\right] \cdot \mathrm{HSO}_{4}$; (b) $\left[\mathrm{Bu}_{4} \mathrm{~N}\right] \cdot \mathrm{Cl} ;(\mathrm{c})$ $\left[\mathrm{Bu}_{4} \mathrm{~N}\right] \cdot \mathrm{NO}_{2}$ and $(\mathrm{d})\left[\mathrm{Bu}_{4} \mathrm{~N}\right] \cdot \mathrm{MeCO}_{2}$. Insets: titration profiles at selected wavelengthsvs. equivalents of anion and species distribution diagram (coordinated dmso molecules are omitted for clarity). 
Table 3. Spectroscopic data and association constants (log $K$ values) obtained from spectrophotometric titrations in dmso solution.

\begin{tabular}{|c|c|c|c|c|}
\hline \multirow[b]{2}{*}{ Anion } & \multicolumn{2}{|c|}{$\left[\mathrm{CuL}^{3}\left(\mathrm{OSMe}_{2}\right)\right]^{2+}$} & \multicolumn{2}{|c|}{$\left[\mathrm{CuL}^{\mathbf{1}}\left(\mathrm{OSMe}_{2}\right)_{2}\right]^{2+a}$} \\
\hline & $\log K_{11}$ & $\lambda_{\max }(\mathrm{nm})$ & $\log K_{11}$ & $\lambda_{\max }(\mathrm{nm})$ \\
\hline $\mathrm{HSO}_{4}^{-}$ & $<2$ & 628 & $3.36(9)$ & 679 \\
\hline $\mathrm{H}_{2} \mathrm{PO}_{4}^{-}$ & $5.09(5)$ & 684 & $3.81(4)$ & 684 \\
\hline $\mathrm{NO}_{2}^{-}$ & $3.65(3)$ & 669 & $5.46(9)$ & 630 \\
\hline $\mathrm{MeCO}_{2}^{-}$ & $>7$ & 692 & $>7$ & 653 \\
\hline $\mathrm{PhCO}_{2}^{-}$ & $>7$ & 674 & $>7$ & 652 \\
\hline $\mathrm{F}^{-}$ & $>7$ & 688 & $>7$ & 695 \\
\hline $\mathrm{Cl}^{-}$ & $5.57(2)$ & 719 & $>7$ & 680 \\
\hline $\mathrm{Br}^{-}$ & $4.22(3)$ & 705 & $3.81(6)$ & 679 \\
\hline
\end{tabular}

${ }^{a}$ Data taken from ref. 14 .

Addition of up to 1 equiv. of $\mathrm{MeCO}_{2}{ }^{-}$or $\mathrm{PhCO}_{2}{ }^{-}$to a solution of $\left[\mathrm{CuL}^{3}\left(\mathrm{OSMe}_{2}\right)\right]^{2+}$ leads to a more pronounced decrease in the intensity of the $\mathrm{d}-\mathrm{d}$ absorption band centred at $621 \mathrm{~nm}$ (Fig. 6, see also Fig. S5, ESI $\dagger$ ), reflecting monodentate binding of the anion to the metal ion. The formation of the $1: 1$ adducts is characterised by higher stability constants $(\log K>7)$. The intensity of the band increases until a second equiv. of the anion has been added, in agreement with the formation of a hydrogen-bond adduct involving the urea group and the anion, as observed in the solid state for $\left[\mathrm{ZnL}^{3}\left(\mathrm{NO}_{3}\right)\right] \mathrm{NO}_{3} \cdot 0.75 \mathrm{MeOH}$ (Fig. 3). The equilibrium constant $(\log K=2.7(1))$ for this step is lower than the values reported for other $N, N^{\prime}$-substituted ureas in the same solvent. ${ }^{34}$ This might be related to the strength of the hydrogen-bonding interaction or to a competitive process between the coordinated and the uncoordinated anions for the urea moiety. Further addition of anion promotes the deprotonation of the urea group with concomitant formation of a hydrogenbond complex between acetate and its conjugated acid, ${ }^{35}$ a process that is complete only after addition of a large excess of anion. When the titration is carried out at a lower concentration of complex $\left(10^{-4} \mathrm{M}\right.$; see Fig. S6, ESI $\dagger$ ) a CT band at $366 \mathrm{~nm}$ centred on the nitro group develops. This results from the deprotonation of the $\mathrm{N}-\mathrm{H}$ group closest to the 3-nitrophenyl substituent. The analysis of the titration data for $\left[\mathrm{CuL}^{3}\left(\mathrm{OSMe}_{2}\right)\right]^{2+}$ provides a $\mathrm{p} K_{\mathrm{a}}$ value of $13.4(3)$, considerably higher than the one determined for the $\mathbf{L}^{1}$ derivative, ${ }^{14}$ where the urea fragment is $N$-coordinated to the metal ion. However, the urea group in $\left[\mathrm{CuL}^{3}\left(\mathrm{OSMe}_{2}\right)\right]^{2+}$ is more acidic than that of 1 -(3,5-bis(trifluoromethyl)phenyl)-3-phenylurea, ${ }^{36}$ most probably as a consequence of the polarisation of one of the $\mathrm{N}-\mathrm{H}$ fragments caused by its interaction with the coordinated anion. Addition of $\mathrm{PhCO}_{2}{ }^{-}$to a solution of $\left[\mathrm{CuL}^{3}\left(\mathrm{OSMe}_{2}\right)\right]^{2+}$ provokes similar changes in the absorption spectrum, yielding $\mathrm{p} K_{\mathrm{a}}=13.54(4)$.

The spectrophotometric titration of $\left[\mathrm{CuL}^{3}\left(\mathrm{OSMe}_{2}\right)\right]^{2+}$ with $\mathrm{F}^{-}$reveals two different processes. The first involves the interaction of a $\mathrm{F}^{-}$anion with the urea moiety through hydrogen bonding, while the second, observed only after addition of a large excess of anion, involves the deprotonation of the $\mathrm{N}-\mathrm{H}$ fragment adjacent to the 3-nitrophenyl group (Fig. S5, ESI†).

The $\log K_{11}$ values obtained for the different anions (Table 3) follow the order $\mathrm{MeCO}_{2}^{-}>\mathrm{Cl}^{-}>\mathrm{H}_{2} \mathrm{PO}_{4}{ }^{-}>$ $\mathrm{Br}^{-}>\mathrm{NO}_{2}^{-}>\mathrm{HSO}_{4}^{-}>\mathrm{NO}_{3}{ }^{-}$. For $\mathrm{MeCO}_{2}{ }^{-}, \mathrm{PhCO}_{2}{ }^{-}$and $\mathrm{F}^{-}$the steep curvature of the titration profiles indicates especially high equilibrium constants $\left(\log K_{11}>7\right.$ ). In contrast, $\mathrm{NO}_{3}{ }^{-}$and $\mathrm{HSO}_{4}{ }^{-}$interact only weakly with the complex. The observed sequence of anion affinity does not follow that expected according to the solvation terms; small anions such as $\mathrm{Cl}^{-}$should be highly solvated, and the endothermic desolvation term should disfavour binding to the metal ion. ${ }^{37}$ The association constants $\log K_{11}$ determined for $\mathrm{MeCO}_{2}{ }^{-}$, $\mathrm{Cl}^{-}$and $\mathrm{H}_{2} \mathrm{PO}_{4}^{-}$are likely related to a cooperative effect between the coordinatively unsaturated metal ion 
and the urea subunit, which is involved in a hydrogen-bonding interaction with the anion, reinforcing the binding to the $\mathrm{Cu}$ (II) ion.

\section{$\underline{\text { Solvent extraction studies }}$}

Liquid-liquid extraction studies were carried out to investigate whether the hydrophobic ligands $\mathbf{L}^{2}$ and $\mathbf{L}^{4}$ were able to transport transition metal salts from water into chloroform. ${ }^{38}$ In all the experiments a solution of the ligand in chloroform $\left(10^{-3} \mathrm{M}\right)$ was stirred for $16 \mathrm{~h}$ with an aqueous solution of $\mathrm{Cu}$ (II) or $\mathrm{Zn}$ (II) sulfate or chloride in the presence of an excess of sodium sulfate or chloride $(0.6 \mathrm{M})$ and analysed as described in the ESI. $\dagger$

Preliminary studies with $\mathbf{L}^{2}$ and copper salts suggested that the receptor is only able to extract significant amounts of $\mathrm{CuCl}_{2}$ and $\mathrm{CuSO}_{4}$, as indicated by the colour intensity of the organic phase (see Fig. S7, ESI $\dagger$ ). In the case of $\mathbf{L}^{4}$ extraction of $\mathrm{CuSO}_{4}$ was judged to be more favourable than $\mathrm{CuCl}_{2}$ and $\mathrm{Cu}\left(\mathrm{NO}_{3}\right)_{2}$. In some cases a third phase developed during the extractions of the latter, which made it impossible to ensure a materials balance when recording the metal distribution between the organic and aqueous phases. Consequently extraction experiments were performed using sulfates and chlorides of $\mathrm{Co}$ (II), $\mathrm{Ni}(\mathrm{II}), \mathrm{Cu}$ (II) and $\mathrm{Zn}(\mathrm{II})$. No uptake of $\mathrm{Co}$ (II) and $\mathrm{Ni}$ (II) into the organic phase was observed from either sulfate or chloride solutions. Consequently the solvent extraction studies described below involve $\mathrm{Cu}$ (II) and $\mathrm{Zn}$ (II) salts.

Solvent extraction of a metal salt of a divalent anion $\mathrm{A}^{2-}$ is represented by eqn (1).

$$
n \mathrm{~L}_{(\mathrm{org})}+\mathrm{M}^{2+}{ }_{(\mathrm{aq})}+\mathrm{A}^{2-}(\mathrm{aq}) \rightleftarrows\left[\mathrm{M}(\mathrm{L})_{n} \mathrm{~A}\right]_{\mathrm{org}}
$$

In the presence of a large excess of anion its concentration is effectively constant in the aqueous phase and the extraction equilibrium constant, $K_{\mathrm{e}}$, and the distribution coefficient, $D$, are defined by eqn (2) and (3).

$$
\begin{aligned}
& K_{\mathrm{e}}=\frac{\left[\mathrm{M}\left(\mathrm{L}_{n}\right) \mathrm{A}\right]_{(\mathrm{org})}}{[\mathrm{L}]_{(\mathrm{org})}^{n}\left[\mathrm{M}^{2+}\right]_{(\mathrm{aq})}} \\
& D=\frac{\left[\mathrm{M}\left(\mathrm{L}_{n}\right) \mathrm{A}\right]_{(\mathrm{org})}}{\left[\mathrm{M}^{2+}\right]_{(\mathrm{aq})}}
\end{aligned}
$$

The molar ratio ( $n$ parameter $)^{39}$ and the equilibrium constant of the extraction process $\left(K_{\mathrm{e}}\right)^{40}$ (see eqn (4)) can then be determined from the slope and the intercept of the straight lines that should be obtained after fitting the experimental data of the plots of $\log D$ versus $\log [\mathrm{L}]$.

$$
\log D=n \log [\mathrm{L}]+\log K_{\mathrm{e}}
$$


Plots of the uptake of $\mathrm{CuSO}_{4}$ by $\mathbf{L}^{2}$ and $\mathbf{L}^{4}$ (Fig. S8, ESI $\dagger$ ), performed in the presence of excess $\mathrm{Na}_{2} \mathrm{SO}_{4}$ at $\mathrm{pH}=5.5,{ }^{41}$ yield a value of $n \sim 1$, which is in agreement with the molecular structures of $\left[\mathrm{CuL}^{\mathbf{1}}\left(\mathrm{SO}_{4}\right)\left(\mathrm{OH}_{2}\right)\right],{ }^{14}\left[\mathrm{CuL}^{\mathbf{1}}\left(\mu-\mathrm{SO}_{4}\right)\right]_{2}$ and $\left[\mathrm{CuL}^{3}\left(\mathrm{SO}_{4}\right)\right]$. Extraction of copper sulfate from acidic media is particularly relevant to commercial operations. ${ }^{1 \mathrm{~b}, \mathrm{c}}$ The $\log K_{\mathrm{e}}$ values obtained from the intercepts (Fig. S8, ESI $\dagger$ ) are 3.2(3) for $\mathbf{L}^{2}$ and 3.6(2) for $\mathbf{L}^{4}$, indicating that the two ligands display similar extraction ability.

The $\mathrm{pH}$ dependence of uptake of $\mathrm{CuSO}_{4}$ by $\mathbf{L}^{2}$ and $\mathbf{L}^{4}$ is shown in Fig. 7. For $\mathbf{L}^{2}$ the Cu-loading is constant, $59 \pm 3 \%$, across the $\mathrm{pH}$ range $0-5.5$. In contrast, for $\mathbf{L}^{4}$ no $\mathrm{Cu}(\mathrm{II})$ uptake is observed below $\mathrm{pH} \sim 2$, and above this $\mathrm{pH}$ the amount of $\mathrm{Cu}(\mathrm{II})$ extracted increases, reaching a maximum of $49 \pm 3 \%$ above $\mathrm{pH} 4$. Two features of the loading behaviour were not expected. The formation constant in water for the cationic $\mathrm{Cu}-$ complex $[\mathrm{Cu}(\text { cyclen })]^{2+}$ is nearly ten orders of magnitude higher than for the dpa analogue, $[\mathrm{Cu}(\mathrm{dpa})]^{2+},(\log$ $K_{11}$ values are 23.4 and 13.8 respectively), ${ }^{42,43}$ and whilst the proton affinity of cyclen is also higher $(\log K=$ 10.6 and 9.6 $)^{44}$ than that of dpa $(\log K=7.3,2.6 \text { and } 1.1)^{45}$ it is not sufficiently so to account for it appearing more favourable for $\mathrm{Cu}^{2+}$ to displace protons from the binding site of dpa than for cyclen. In an extraction experiment it may be the case that the stability of the salts $\left(\mathbf{L H}_{n}\right)\left(\mathrm{HSO}_{4}\right)_{n}$ or $\left(\mathbf{L H}_{n}\right)\left(\mathrm{SO}_{4}\right)_{n / 2}$ in the organic phase is significantly higher for $\mathbf{L}^{4}$ than for $\mathbf{L}^{2}$ making it more difficult to displace protons by $\mathrm{Cu}^{2+}$. Another factor which would impact on these loading data is the relative solubility of the protonated and coppercomplexed forms of the ligands. The high hydration energy of the sulfate anion will influence this greatly, together with the observation that in water cyclen is expected to be present in its doubly protonated form below $\mathrm{pH} \sim 9.6$, while the diprotonated form of dpa dominates the speciation in solution only below $\mathrm{pH} 3.0$ (see Fig. S9, ESI†े).

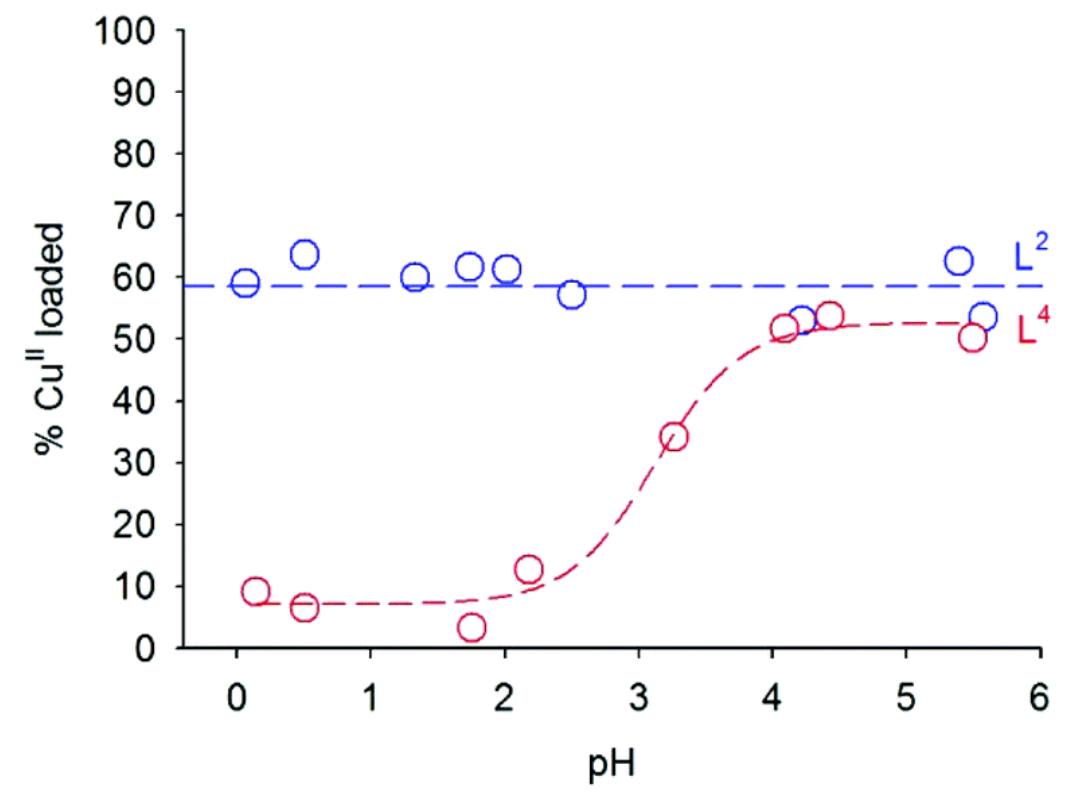

Fig. 7. $\mathrm{pH}$ profiles for $\mathrm{Cu}(\mathrm{II})$ loading by $10^{-3} \mathrm{M} \mathrm{CHCl}_{3}$ solutions of $\mathbf{L}^{2}$ and $\mathbf{L}^{4}$ ligands from equal volumes of $10^{-3} \mathbf{M}$ aqueous $\mathrm{CuSO}_{4}$.

The other unexpected feature of the $\mathrm{pH}$-profiles for $\mathrm{Cu}$ uptake is the maximum loading of copper by $\mathbf{L}^{4}$ being only ca. $50 \%$ of theory for the formation of $\left[\mathrm{CuL}^{4}\left(\mathrm{SO}_{4}\right)\right]$. The dependence of uptake on the concentration of $\mathrm{CuSO}_{4}$ in water ( $\mathrm{pH} 5.5$ ) is shown in Fig. 8a. This confirms that the maximum uptake is $48 \pm 2 \%$ and also shows that loading is independent of the concentration of $\mathrm{CuSO}_{4}$ in the aqueous phase. In contrast, for $\mathbf{L}^{2} 20$ equiv. of $\mathrm{CuSO}_{4}$ is needed to reach a 'plateau' in which $70 \%$ of $\mathrm{Cu}$ is loaded. The dependence of loading on sulfate concentration (see Fig. 8b) is also very different for $\mathbf{L}^{2}$ and $\mathbf{L}^{4}$ with the Cu-uptake by $\mathbf{L}^{4}(53 \pm 2 \%$ ) 
varying very little whilst that by $\mathbf{L}^{2}$ increases significantly and approaches that for $\mathbf{L}^{4}$ when 600 equivalents of $\mathrm{Na}_{2} \mathrm{SO}_{4}$ have been added to the aqueous phase. The origins of the remarkable differences in behaviour of $\mathbf{L}^{2}$ and $\mathbf{L}^{4}$ in transporting $\mathrm{CuSO}_{4}$ into chloroform are unclear. The similarity of the coordination chemistry shown by their analogues, $\mathbf{L}^{\mathbf{1}}$ and $\mathbf{L}^{\mathbf{3}}$, in a single solvent and in the solid state (see above) suggests that differences in the relative stabilities and solubilities of their sulfate salts and copper sulfate complexes in the two solvents contribute to the unusual behaviour in solvent extraction experiments.
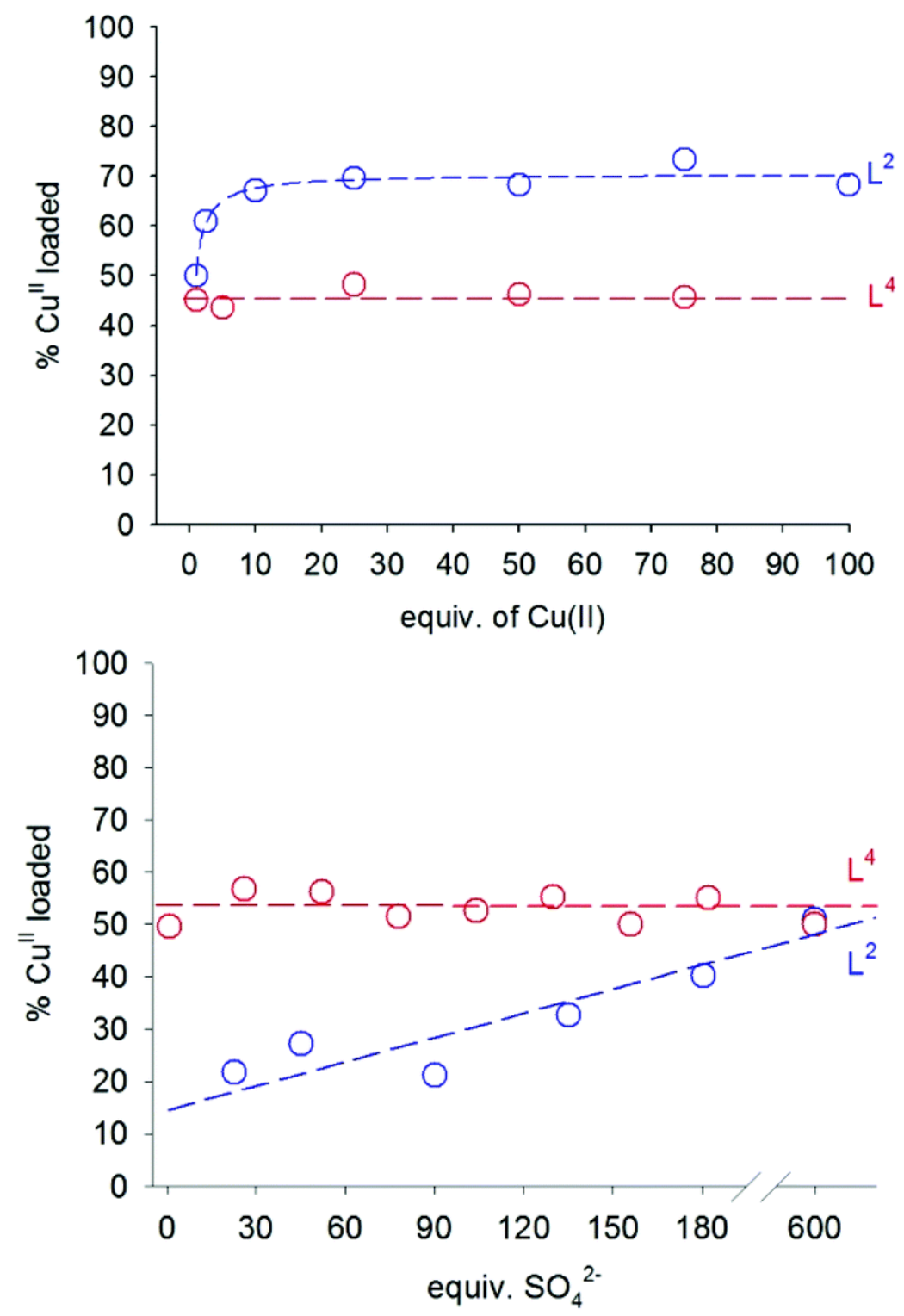

Fig. 8. Loadings of $\mathrm{CuSO}_{4}$ by $10^{-3} \mathrm{M} \mathrm{CHCl}_{3}$ solutions of $\mathbf{L}^{2}$ and $\mathbf{L}^{4}$ as a function on the $\mathrm{Cu}$ (II) concentration (top) and the sulfate concentration (bottom) in the aqueous phase $(\mathrm{pH}=5.5)$.

When a mixed metal aqueous solution of $\mathrm{Co}(\mathrm{II}), \mathrm{Ni}(\mathrm{II}), \mathrm{Cu}(\mathrm{II})$ and $\mathrm{Zn}(\mathrm{II})$ as their sulfates $\left(10^{-3} \mathrm{M}\right.$, pH 5.5) was contacted a chloroform solution $\left(10^{-3} \mathbf{M}\right)$ of $\mathbf{L}^{2}$ or $\mathbf{L}^{4}$, only $\mathrm{CuSO}_{4}$ was extracted suggesting that they could provide useful selectivity in hydrometallurgical concentration and separation of copper. Whilst acid stripping to recover the copper from $\mathbf{L}^{4}$ should be possible (see Fig. 7), practicable reagents will need to have better loading efficiencies and better solubility in hydrocarbon diluents to merit development. 
Preliminary tests showed that $\mathbf{L}^{2}$ and $\mathbf{L}^{4}$ were capable of extracting $\mathrm{Zn}$ (II) as well as $\mathrm{Cu}$ (II) from chloride solutions (no $\mathrm{Co}(\mathrm{II})$ or $\mathrm{Ni}(\mathrm{II})$ were loaded). A precipitate separated in extractions of $\mathrm{CuCl}_{2}$ by $\mathbf{L}^{4}$, so studies of the efficiency of extraction and of the stoichiometry of complex formation in chloroform used only $\mathbf{L}^{2}$ and allowed comparison with results for sulfate solutions. Loadings as a function of $\mathrm{pH}, \mathrm{Cu}$ concentration and anion concentration are provided in Fig. S11, ESI. $\dagger$ A higher maximum loading of $\mathrm{CuCl}_{2}(91 \pm 2 \%)$ than of $\mathrm{CuSO}_{4}(70 \pm 2 \%)$ was observed as might be expected, given the chloride ion's lower hydration energy and better metal ligating properties. As for the sulfate systems, the stoichiometries of complex formation in chloroform are not consistent with maximum loadings. A plot of $\log D v s \log [\mathrm{L}]$ (Fig. S8, ESI $\dagger$ ) has a slope of $\sim 2$ and the consequent $2: 1$ molar ratio of $\mathbf{L}^{2}$ to $\mathrm{Cu}$ (II) indicates that the maximum loading should be $50 \%$. It is probable that a mixture of species is transferred to the organic phase (the $\log D v s . \log [\mathrm{L}]$ plot is slightly curved). One of these species might be the $\left[\mathrm{CuL}^{2} \mathrm{Cl}_{2}\right]$ neutral complex ${ }^{46}$ as mass spectra (Fig. S10, ESI $\dagger$ ) show that both $\left[\mathrm{CuL}^{2} \mathrm{Cl}\right]^{+}$and $\left[\mathbf{L}^{2}+\mathrm{Cl}\right]^{-}$species are present in solution, together with $\left(\left[\mathrm{Cu}\left(\mathbf{L}^{2}\right)_{2} \mathrm{Cl}\right]^{+}\right)$, which might exhibit a structure similar to that reported by Glerup et al. ${ }^{47}$ The formation of several species which display different metal/ligand ratios during extraction has been previously reported by Ohmuro et $a l .^{39 \mathrm{~d}}$

The influence of $\mathrm{pH}$ and of the concentration of copper and of chloride on $\mathrm{Cu}$ (II) loading was investigated following similar procedures to those described for sulfate. The amount of $\mathrm{Cu}$ (II) loaded into the organic phase $(90 \pm 3 \%$ ) is not affected by $\mathrm{pH}$ (in the range 0 to 5.5), nor by the concentration of $\mathrm{Cu}$ (II). In contrast, the uptake of copper is very dependent on the concentration of chloride in the aqueous phase and 60 equivalents are required to reach the 'plateau' in which $90 \%$ loading.

Only copper was extracted from an aqueous solution containing equimolar concentrations of $\mathrm{Co}(\mathrm{II}), \mathrm{Ni}$ (II), $\mathrm{Cu}$ (II) and $\mathrm{Zn}$ (II) chlorides, showing the same selectivity pattern as that observed for extraction from sulfate media.

\section{Conclusions}

The ditopic ligand $\mathbf{L}^{3}$ containing a cyclen unit for cation binding and a urea motif for anion recognition has been prepared and characterised. X-ray crystal structures of $\mathrm{CuSO}_{4}$ complexes show that $\mathrm{SO}_{4}{ }^{2-}$ anion is involved in cooperative binding with simultaneous coordination of the anion to the metal ion and hydrogenbonding to the urea subunit. In contrast, the $\mathrm{NO}_{3}{ }^{-}$anions in $\left[\mathrm{ZnL}^{3}\left(\mathrm{NO}_{3}\right)_{2}\right]$ do not show cooperative binding as one interacts only with the zinc ion, and the second is involved only in hydrogen-bonding with the urea moiety.

Spectrophotometric and ${ }^{1} \mathrm{H}$ NMR titrations of the formation of the $\left[\mathrm{CuL}^{3}\left(\mathrm{OSMe}_{2}\right)\right]^{2+}$ complex and its $\mathrm{Zn}$ (II) analogue show that all investigated anions bind to the coordinatively unsaturated metal ion in dmso solution with an affinity sequence $\mathrm{MeCO}_{2}^{-}>\mathrm{Cl}^{-}>\mathrm{H}_{2} \mathrm{PO}_{4}{ }^{-}>\mathrm{Br}^{-}>\mathrm{NO}_{2}{ }^{-}>\mathrm{HSO}_{4}{ }^{-}>\mathrm{NO}_{3}{ }^{-}$. Addition of large excesses of relatively basic anions such as $\mathrm{MeCO}_{2}{ }^{-}$and $\mathrm{F}^{-}$results in the deprotonation of the urea group, as evidenced by the charge transfer bands developed in the absorption spectra.

The ability of $\mathbf{L}^{1}$ and $\mathbf{L}^{3}$ to form stable metal salt complexes in solution and in the solid state is also found in solvent extraction experiments using their lipophilic analogues, $\mathbf{L}^{2}$ and $\mathbf{L}^{4}$. Whilst these reagents show evidence for highly selective extraction of $\mathrm{Cu}$ (II) in the presence of $\mathrm{Co}(\mathrm{II}), \mathrm{Ni}$ (II) and $\mathrm{Zn}$ (II), their loading capacities are not sufficient to allow operation of efficient hydrometallurgical recovery processes. Investigation of the mechanisms of extraction suggest that more than one complex is formed in the organic phase and indicate that more lipophilic versions would be needed to develop efficient metal recovery processes. 


\section{Experimental section}

\section{$\underline{\text { Materials }}$}

1-(Chloromethyl)-2-isocyanatobenzene (1), 4-hexylaniline (2), bis(pyridin-2-ylmethyl)amine (4), 1,4,7,10tetraazacyclododecane, 1-(bromomethyl)-4-(tert-butyl)benzene and tert-butyl-(oxycarbonyloxy)succinimide were obtained from commercial sources. Solvents were of reagent grade and used without further purification.

Caution: Although we have experienced no difficulties with the perchlorate salts, these should be regarded as potentially explosive and handled with care.

\section{General methods}

Elemental analyses were carried out on a ThermoQuest Flash EA 1112 elemental analyser. ESI-TOF mass spectra were recorded from $\mathrm{MeOH} / \mathrm{CH}_{2} \mathrm{Cl}_{2} / \mathrm{MeCN}, \mathrm{MeOH} / \mathrm{MeCN}, \mathrm{MeCN}, \mathrm{MeOH}, \mathrm{MeOH} / \mathrm{H}_{2} \mathrm{O} / \mathrm{MeCN}$ or $\mathrm{MeOH} / \mathrm{MeCN} / \mathrm{CHCl}_{3}$ solutions, using a LC-Q-q-TOF Applied Biosystems QSTAR Elite spectrometer in the positive mode. IR spectra were recorded using a Bruker Vector 22 spectrophotometer equipped with a Golden Gate attenuated total reflectance (ATR) accesory (Specac). ${ }^{1} \mathrm{H}$ and ${ }^{13} \mathrm{C}$ NMR spectra were recorded at $25{ }^{\circ} \mathrm{C}$ on Bruker Avance 300 and Bruker Avance 500 spectrometers, and spectral assignments (see Scheme S1, ESI $\dagger$ ) were based in part on 2D COSY, HSQC and HMBC experiments. UV/vis spectra were recorded with a Perkin-Elmer Lambda 900 spectrophotometer; those performed in solution were recorded with quartz cells (path length: $1 \mathrm{~cm}$ ) and the cell holder was thermostated at $25.0{ }^{\circ} \mathrm{C}$, through circulating water. Anion binding studies were performed by monitoring the spectral changes of a $10^{-3} \mathrm{M}$ solution of complex $\left[\mathrm{CuL}^{3}\left(\mathrm{ClO}_{4}\right)_{2}\right] \cdot 2 \mathrm{H}_{2} \mathrm{O}$ in dmso upon addition of a $0.1 \mathrm{M}$ solution of the corresponding tetrabutylammonium salt. Binding constants were obtained by using a simultaneous fit of the UV/vis absorption spectral changes at 7-12 selected wavelengths in the range 500-1200 nm. A minimum of 26 absorbance data points at each of these wavelengths was used, and all spectrophotometric titration curves were fitted with the HYPERQUAD program. ${ }^{48}$

1-(2-(Chloromethyl)phenyl)-3-(4-hexylphenyl)urea $\quad$ (3b). A solution of 1-(chloromethyl)-2isocyanatobenzene $(\mathbf{1})(0.700 \mathrm{~mL}, 5.076 \mathrm{mmol})$ and 4-hexylaniline $(2)(1.088 \mathrm{~mL}, 5.076 \mathrm{mmol})$ in diethyl ether $(100 \mathrm{~mL})$ was stirred at room temperature for $48 \mathrm{~h}$. The precipitate formed was isolated by filtration and washed with diethyl ether $(3 \times 10 \mathrm{~mL})$ to give $1.533 \mathrm{~g}$ of the desired compound $(88 \%)$ as a white solid. ${ }^{1} \mathrm{H}$ NMR (500 MHz, dmso- $\left.d_{6}, 298 \mathrm{~K}\right): \delta 9.41(\mathrm{~s}), 9.35(\mathrm{~s}), 8.38(\mathrm{~m}), 8.26(\mathrm{~s}), 7.88(\mathrm{~m}), 7.41-7.37(\mathrm{~m})$, 7.34-7.28 (m), 7.26-7.17 (m), $7.08\left(\mathrm{~d},{ }^{3} J=8.2 \mathrm{~Hz}\right), 7.05-7.02(\mathrm{~m}), 6.98(\mathrm{~m}), 6.89(\mathrm{~m}), 5.67(\mathrm{~s}), 5.25(\mathrm{~s})$, $4.86(\mathrm{~s}), 4.53(\mathrm{~s}), 2.58(\mathrm{~m}), 2.49(\mathrm{~m}), 1.52(\mathrm{~m}), 1.25(\mathrm{~m}), 0.84(\mathrm{~m}) .{ }^{13} \mathrm{C}$ NMR $\left(125.8 \mathrm{MHz}, \mathrm{dmso}-d_{6}, 298\right.$ $\mathrm{K}): \delta 153.0,152.9,152.0,142.8,137.8,137.5,137.5,136.5,135.9,135.7,131.4,131.3,130.7,129.6,129.3$, 129.1, 128.8, 128.6, 128.6, 128.1, 127.5, 127.5, 125.7, 125.1, 124.5, 123.2, 123.0, 122.5, 122.3, 121.3, 118.6, 118.3, 113.8, 69.9, 67.6, 60.9, 43.7, 34.8, 34.7, 34.6, 31.3, 31.2, 31.2, 31.0, 28.5, 28.4, 28.3, 22.2, 22.2, 14.1, 14.1. MS-ESI ${ }^{+}, m / z(\% \mathrm{BPI}):[3+\mathrm{H}]^{+}, 345.2(1 \%) ;[3-\mathrm{Cl}]^{+}, 309.2(100 \%)$. Elem. Anal. Calcd for $\mathrm{C}_{20} \mathrm{H}_{25} \mathrm{ClN}_{2} \mathrm{O}: \mathrm{C}, 69.7 ; \mathrm{H}, 7.3 ; \mathrm{N}, 8.1 \%$. Found: C, 69.7; H, 6.8; N, 8.0\%. IR: $3286 v(\mathrm{~N}-\mathrm{H}), 2958,2925$, $2853 v(\mathrm{C}-\mathrm{H}), 1641 v(\mathrm{C}=\mathrm{O}), 1606,1588,1487,1450 v(\mathrm{C}=\mathrm{C}), 1548 \delta(\mathrm{N}-\mathrm{H}), 669 v(\mathrm{C}-\mathrm{Cl}) \mathrm{cm}^{-1}$.

1-(2-((Bis(pyridin-2-ylmethyl)amino)methyl)phenyl)-3-(4-hexylphenyl)urea $\quad\left(\mathrm{L}^{2}\right)$. A solution of compound 3b (0.923 g, $2.677 \mathrm{mmol})$, bis(pyridin-2-ylmethyl)amine (4) $(0.452 \mathrm{~mL}, 2.434 \mathrm{mmol}), N, N$ diisopropylethylamine $(0.848 \mathrm{~mL}, 4.868 \mathrm{mmol})$ and a catalytic amount of $\mathrm{KI}$ in acetonitrile $(50 \mathrm{~mL})$ was heated to reflux with stirring for 3 days. The resulting solution was filtered while hot and the filtrate concentrated to dryness. The residue was extracted with chloroform $(5 \times 50 \mathrm{~mL})$ and water $(25 \mathrm{~mL})$, the organic layer combined and dried over anhydrous $\mathrm{Na}_{2} \mathrm{SO}_{4}$, and the solvent evaporated under reduced pressure. The resulting oil was purified on a CombiFlash RF-200, using a 12 g-silica gel column and $\mathrm{CH}_{2} \mathrm{Cl}_{2}$ as eluent to obtain pure product $\mathbf{L}^{2}$ as a pale yellow oil $(0.631 \mathrm{~g}, 50 \%)$. ${ }^{1} \mathrm{H} \mathrm{NMR}\left(500 \mathrm{MHz}, \mathrm{CDCl}_{3}\right.$, 
$298 \mathrm{~K}): \delta 10.80$ (s, 1H, H14), 8.85 (s, $1 \mathrm{H}, \mathrm{H} 16), 8.53$ (ddd, $2 \mathrm{H}, \mathrm{H} 1,{ }^{3} J=4.9 \mathrm{~Hz},{ }^{4} J=1.7 \mathrm{~Hz},{ }^{4} J=0.8 \mathrm{~Hz}$ ), $8.35(\mathrm{~m}, 1 \mathrm{H}, \mathrm{H} 12), 7.56\left(\mathrm{td}, 2 \mathrm{H}, \mathrm{H} 3,{ }^{3} J=7.7 \mathrm{~Hz},{ }^{4} J=1.8 \mathrm{~Hz}\right), 7.53(\mathrm{~m}, 2 \mathrm{H}, \mathrm{H} 18), 7.27-7.24$ (m, H4 and $\mathrm{H} 11), 7.16-7.12$ (m, 3H, H2 and H19), 7.07 (m, 1H, H9), 6.88 (td, $1 \mathrm{H}, \mathrm{H} 10,{ }^{3} J=7.4 \mathrm{~Hz},{ }^{4} \mathrm{~J}=1.2 \mathrm{~Hz}$ ), 3.85 (s, 4H, H6), 3.70 (s, 2H, H7), 2.57 (m, 2H, H21), 1.62 (m, 2H, H22), 1.39-1.26 (m, 6H, H23, H24 and H25), 0.90 (m, 3H, H26). ${ }^{13} \mathrm{C}$ NMR (125.8 MHz, $\left.\mathrm{CDCl}_{3}, 298 \mathrm{~K}\right): \delta 158.0 \mathrm{C} 5,153.4 \mathrm{C} 15,149.3 \mathrm{C} 1,140.2 \mathrm{C} 13$, 137.9 C17, 137.0 C3, 136.8 C20, 130.0 C9, 129.0 C19, 128.8 C11, 124.2 C4, 124.1 C8, 122.7 C2, 121.3 C10, 119.1 C12, 118.6 C18, 59.7 C6, 58.5 C7, 35.4 C21, 31.9 C23, 31.7 C22, 29.1 C24, 22.7 C25, 14.2 C26. MS-ESI ${ }^{+}, m / z(\% B P I):\left[\mathbf{L}^{2}+\mathrm{Na}\right]^{+}, 530.3(24 \%) ;\left[\mathbf{L}^{2}+\mathbf{H}\right]^{+}, 508.3(100 \%)$. Elem. Anal. Calcd for $\mathrm{C}_{32} \mathrm{H}_{37} \mathrm{~N}_{5} \mathrm{O} \cdot 0.5 \mathrm{H}_{2} \mathrm{O}: \mathrm{C}, 74.4 ; \mathrm{H}, 7.4 ; \mathrm{N}, 13.6 \%$. Found: C, 74.9; H, 7.6; N, 13.5\%. IR: $3330-3190 v(\mathrm{~N}-\mathrm{H})$, $3118-2853 v(\mathrm{C}-\mathrm{H}), 1705 v(\mathrm{C}=\mathrm{O}), 1590,1570,1478,1451 v(\mathrm{Ph} / \mathrm{Py}), 1531 \delta(\mathrm{N}-\mathrm{H}), 753 \gamma(\mathrm{C}-\mathrm{H}) \mathrm{cm}^{-1}$.

Di-tert-butyl-1,4,7,10-tetraazacyclododecane-1,7-dicarboxylate (5). This compound was prepared according to the literature. ${ }^{19} \mathrm{~A}$ solution of $1,4,7,10$-tetraazacyclododecane $(0.714 \mathrm{~g}, 4.145 \mathrm{mmol})$ and tertbutyl-(oxycarbonyloxy)succinimide $(1.820 \mathrm{~g}, 8.289 \mathrm{mmol})$ in chloroform $(35 \mathrm{~mL})$ was stirred at room temperature for $48 \mathrm{~h}$. The solvent was removed by rotary evaporation and the residue was dissolved in chloroform $(30 \mathrm{~mL})$ and washed with an aqueous solution of $\mathrm{NaOH} 3 \mathrm{M}(3 \times 30 \mathrm{~mL})$. The organic layer was combined and dried over anhydrous $\mathrm{Na}_{2} \mathrm{SO}_{4}$, and the solvent was evaporated under reduced pressure. The residue was dried under vacuum for several hours to give $1.495 \mathrm{~g}$ of the desired compound (84\%) as a pale yellow oil. ${ }^{1} \mathrm{H}$ NMR (500 MHz, $\left.\mathrm{CDCl}_{3}, 298 \mathrm{~K}\right): \delta 3.33(\mathrm{~m}, 8 \mathrm{H}), 2.81(\mathrm{~m}, 8 \mathrm{H}), 1.41(\mathrm{~s}, 18 \mathrm{H}) .{ }^{13} \mathrm{C}$ NMR (125.8 MHz, $\left.\mathrm{CDCl}_{3}, 298 \mathrm{~K}\right): \delta 156.3,156.2,79.8,79.6,50.9,50.5,50.3,50.1,50.1,49.4,48.9,48.3,28.6$, 28.6. $\mathrm{MS}-E S I^{+}, \mathrm{m} / \mathrm{z}$ (\%BPI): $[\mathbf{5}+\mathrm{H}]^{+}, 373.3$ (100\%). Elem. Anal. Calcd for $\mathrm{C}_{18} \mathrm{H}_{36} \mathrm{~N}_{4} \mathrm{O}_{4} \cdot 0.5 \mathrm{CHCl}_{3}: \mathrm{C}, 51.4$; H, 8.5; N, 13.0\%. Found: C, 52.0; H, 8.5; N, 12.6\%. IR: 3010-2827 v(C-H), $1682 v(\mathrm{C}=\mathrm{O}), 1157 v_{\mathrm{a}}(\mathrm{N}-\mathrm{C})$, $752 \gamma(\mathrm{C}-\mathrm{H}) \mathrm{cm}^{-1}$.

\section{Di-tert-butyl-4-(2-(3-(3-nitrophenyl)ureido)benzyl)-1,4,7,10-tetraazacyclododecane-1,7-dicarboxylate}

(6a). A solution of 1-(2-(chloromethyl)phenyl)-3-(3-nitrophenyl)urea (3a) (0.283 g, $0.925 \mathrm{mmol})$ in acetonitrile $(50 \mathrm{~mL})$ was added dropwise to a suspension of compound $5(2.000 \mathrm{~g}, 4.627 \mathrm{mmol})$ and potassium carbonate $(1.292 \mathrm{~g}, 9.255 \mathrm{mmol})$ in acetonitrile $(100 \mathrm{~mL})$ and stirred at room temperature for $16 \mathrm{~h}$. The suspension was filtered and the filtrate concentrated to dryness. The residue was extracted with chloroform $(5 \times 50 \mathrm{~mL})$ and water $(25 \mathrm{~mL})$, the organic layer combined and dried over anhydrous $\mathrm{Na}_{2} \mathrm{SO}_{4}$, and the solvent evaporated under reduced pressure. The resulting oil was purified on a CombiFlash RF-200, using a 12 g-silica gel column and $\mathrm{CH}_{2} \mathrm{Cl}_{2} / \mathrm{MeOH}$ as eluent (from 0 to $5 \%$ of methanol; the desired compound eluted from 1.5 to $3 \%)$ to give pure product $6 \mathbf{a}$ as a yellow foam $(0.466 \mathrm{~g}, 74 \%) .{ }^{1} \mathrm{H}$ NMR $(500$ $\left.\mathrm{MHz}, \mathrm{CDCl}_{3}, 298 \mathrm{~K}\right): \delta 9.68(\mathrm{~s}), 8.89(\mathrm{~s}), 8.42(\mathrm{~m}), 7.87-7.80(\mathrm{~m}), 7.71(\mathrm{~m}), 7.32(\mathrm{~m}), 7.24(\mathrm{~m}), 6.94(\mathrm{~m})$, $4.02(\mathrm{~m}), 3.65-2.56(\mathrm{~m}), 1.36-1.27(\mathrm{~m}) .{ }^{13} \mathrm{C} \mathrm{NMR}\left(125.8 \mathrm{MHz}, \mathrm{CDCl}_{3}, 298 \mathrm{~K}\right): \delta 155.3,153.1,148.5,140.9$, 138.0, 135.0, 131.5, 129.3, 128.9, 124.9, 124.2, 123.5, 116.6, 113.0, 81.1, 55.3, 53.3, 48.7, 48.2, 47.1, 28.2. MS-ESI ${ }^{+}, m / z$ (\%BPI): $[6 \mathbf{a}+\mathrm{H}]^{+}, 642.4(100 \%)$. Elem. Anal. Calcd for $\mathrm{C}_{32} \mathrm{H}_{47} \mathrm{~N}_{7} \mathrm{O}_{7} \cdot 0.5 \mathrm{CH}_{2} \mathrm{Cl}_{2}: \mathrm{C}, 57.1 ; \mathrm{H}$, 7.1; N, 14.3\%. Found: C, 57.1; H, 7.0; N, 13.7\%. IR: $3268 v(\mathrm{~N}-\mathrm{H}), 3130-2860 v(\mathrm{C}-\mathrm{H}), 1692 v(\mathrm{C}=\mathrm{O}), 1589$, $1479,1452 v(\mathrm{C}=\mathrm{C}), 1526 v_{\mathrm{a}}\left(\mathrm{NO}_{2}\right), 1346 v_{\mathrm{s}}\left(\mathrm{NO}_{2}\right), 1154 v_{\mathrm{a}}(\mathrm{N}-\mathrm{C}), 749 \gamma(\mathrm{C}-\mathrm{H}) \mathrm{cm}^{-1}$.

\section{Di-tert-butyl-4-(4-(tert-butyl)benzyl)-10-(2-(3-(3-nitrophenyl)ureido)benzyl)-1,4,7,10-}

tetraazacyclododecane-1,7-dicarboxylate (7a).A solution of 1-(bromomethyl)-4-(tert-butyl)benzene (0.186 $\mathrm{mL}, 0.984 \mathrm{mmol})$, compound $6 \mathbf{a}(0.449 \mathrm{~g}, 0.656 \mathrm{mmol}), N, N$-diisopropylethylamine $(0.231 \mathrm{~mL}, 1.312$ mmol) and a catalytic amount of KI in acetonitrile $(50 \mathrm{~mL})$ was heated to reflux with stirring for $16 \mathrm{~h}$. The resulting solution was filtered while hot and the filtrate concentrated to dryness. The residue was extracted with chloroform $(5 \times 25 \mathrm{~mL})$ and water $(15 \mathrm{~mL})$, the organic layer combined and dried over anhydrous $\mathrm{Na}_{2} \mathrm{SO}_{4}$, and the solvent evaporated under reduced pressure. The resulting oil was purified on a CombiFlash RF-200, using a 12 g-silica gel column and Hex/EtOAc as eluent (from 0 to $100 \%$ of ethyl acetate; the desired compound eluted from 20 to $50 \%)$ to give pure product $7 \mathbf{a}$ as a yellow foam $(0.277 \mathrm{~g}, 54 \%) .{ }^{1} \mathrm{H}$ NMR (500 MHz, $\left.\mathrm{CDCl}_{3}, 298 \mathrm{~K}\right): \delta 9.75$ (s), $9.68(\mathrm{~s}), 9.47$ (s), $9.31(\mathrm{~s}), 8.37$ (s), $8.31(\mathrm{~s}), 8.10\left(\mathrm{~d},{ }^{3} J=7.9\right.$ 
$\mathrm{Hz}), 7.90\left(\mathrm{~d},{ }^{3} J=7.9 \mathrm{~Hz}\right), 7.78\left(\mathrm{ddd},{ }^{3} J=8.2 \mathrm{~Hz},{ }^{4} \mathrm{~J}=2.2 \mathrm{~Hz},{ }^{4} \mathrm{~J}=0.8 \mathrm{~Hz}\right), 7.38\left(\mathrm{t},{ }^{3} \mathrm{~J}=8.2 \mathrm{~Hz}\right), 7.34\left(\mathrm{~d},{ }^{3} \mathrm{~J}=\right.$ $8.2 \mathrm{~Hz}), 7.26(\mathrm{~m}), 7.13\left(\mathrm{~d},{ }^{3} J=7.6 \mathrm{~Hz}\right), 7.10(\mathrm{~m}), 6.95(\mathrm{~m}), 3.73(\mathrm{~m}), 3.34-2.66(\mathrm{~m}), 1.48(\mathrm{~s}), 1.41(\mathrm{~s}), 1.30$ (s), 1.19 (s). ${ }^{13} \mathrm{C}$ NMR $\left(125.8 \mathrm{MHz}, \mathrm{CDCl}_{3}, 298 \mathrm{~K}\right): \delta 157.0,156.2,155.7,153.4,150.3,148.5,141.7,139.0$, 132.0, 130.0, 129.4, 128.2, 127.0, 125.1, 124.6, 122.9, 122.5, 116.3, 113.3, 81.0, 80.1, 79.4, 60.2, 58.9, 56.4, 55.9, 54.9, 53.4, 52.8, 52.6, 50.8, 48.7, 47.8, 45.8, 44.8, 34.5, 31.3, 28.6, 28.5, 28.3. MS-ESI ${ }^{+}, \mathrm{m} / \mathrm{z}(\% \mathrm{BPI})$ : $[7 \mathbf{a}+\mathrm{H}]^{+}, 788.5(100 \%)$. Elem. Anal. Calcd for $\mathrm{C}_{43} \mathrm{H}_{61} \mathrm{~N}_{7} \mathrm{O}_{7}: \mathrm{C}, 65.5 ; \mathrm{H}, 7.8 ; \mathrm{N}, 12.4 \%$. Found: $\mathrm{C}, 65.4 ; \mathrm{H}$, 8.0; N, 12.0\%. IR: 3320, $3291 v(\mathrm{~N}-\mathrm{H}), 2965-2810 v(\mathrm{C}-\mathrm{H}), 1688,1664 v(\mathrm{C}=\mathrm{O}), 1591,1479,1450 v(\mathrm{C}=\mathrm{C})$, $1525 v_{\mathrm{a}}\left(\mathrm{NO}_{2}\right), 1347 v_{\mathrm{s}}\left(\mathrm{NO}_{2}\right), 1151 v_{\mathrm{a}}(\mathrm{N}-\mathrm{C}) \mathrm{cm}^{-1}$.

\section{1-(2-((7-(4-(tert-Butyl)benzyl)-1,4,7,10-tetraazacyclododecan-1-yl)methyl)phenyl)-3-(3-}

nitrophenyl)urea $\left(\mathbf{L}^{3}\right)$. A solution of compound $7 \mathbf{a}(0.250 \mathrm{~g}, 0.317 \mathrm{mmol})$ and trifluoroacetic acid $(5 \mathrm{~mL})$ in chloroform $(5 \mathrm{~mL})$ was stirred at room temperature for $16 \mathrm{~h}$. The solvent was removed by rotary evaporation and the residue was dissolved in chloroform $(30 \mathrm{~mL})$. The acid in excess was neutralised with an aqueous solution of $\mathrm{NaOH} 1 \mathrm{M}$ and the organic layer washed with distilled water $(2 \times 15 \mathrm{~mL})$. The organic phase was dried over anhydrous $\mathrm{Na}_{2} \mathrm{SO}_{4}$, and the solvent evaporated under reduced pressure to give pure product $\mathbf{L}^{3}$ as an orange oil which became a solid after remaining under vacuum for several days $(0.179 \mathrm{~g}, 96 \%) .{ }^{1} \mathrm{H}$ NMR $\left(500 \mathrm{MHz}, \mathrm{CDCl}_{3}, 298 \mathrm{~K}\right): \delta 10.46(\mathrm{~s}, 1 \mathrm{H}), 8.79(\mathrm{~s}, 1 \mathrm{H}), 8.06(\mathrm{~m}, 2 \mathrm{H}, \mathrm{H} 17$ and $\mathrm{H} 27), 7.76(\mathrm{~m}, 1 \mathrm{H}, \mathrm{H} 23)$, 7.72 (m, 1H, H25), 7.36-7.28 (m, 2H, H16 and H24), 7.20 (d, 2H, H4, $\left.{ }^{3} J=8.2 \mathrm{~Hz}\right), 7.12-7.04$ (m, 3H, H5 and H14), 7.00 (td, $1 \mathrm{H}, \mathrm{H} 15,{ }^{3} \mathrm{~J}=7.4 \mathrm{~Hz},{ }^{4} J=1.1 \mathrm{~Hz}$ ), 3.65 (s, 2H, H12), 3.49 (s, 2H, H7), 2.93-2.26 (m, H9 and H10), 2.71 (m, H11), 2.57 (m, H8), 1.17 (s, 9H, H1). ${ }^{13} \mathrm{C}$ NMR (125.8 MHz, $\mathrm{CDCl}_{3}, 298 \mathrm{~K}$ ): $\delta 153.1$ C20, 150.2 C3, 148.5 C26, 141.6 C22, 138.6 C18, 135.4 C6, 130.0 C24, 129.3 C14, 128.7 C16, 128.4 C5, 128.0 C13, 125.3 C4, 124.4 C23, 123.1 C15, 122.5 C17, 116.3 C25, 113.2 C27, 60.8 C12, 59.3 C7, 53.2 C11, 51.1 C8, 46.7 C9, 46.4 C10, 34.4 C2, 31.3 C1. MS-ESI ${ }^{+}, \mathrm{m} / z(\% \mathrm{BPI}):\left[\mathbf{L}^{3}+\mathrm{H}\right]^{+}, 588.4$ (100\%). Elem. Anal. Calcd for $\mathrm{C}_{33} \mathrm{H}_{45} \mathrm{~N}_{7} \mathrm{O}_{3}$ : C, 67.4; H, 7.7; N, 16.7\%. Found: C, 68.0; H, 7.5; N, 16.0\%. IR: 3330$3183 v(\mathrm{~N}-\mathrm{H}), 2962-2820 v(\mathrm{C}-\mathrm{H}), 1700 v(\mathrm{C}=\mathrm{O}), 1613,1590,1483,1449 v(\mathrm{C}=\mathrm{C}), 1520 v_{\mathrm{a}}\left(\mathrm{NO}_{2}\right), 1349$ $v_{\mathrm{s}}\left(\mathrm{NO}_{2}\right) \mathrm{cm}^{-1}$. Slow evaporation of a solution of the receptor in 1-butanol provided yellow single crystals suitable for X-ray diffraction analysis.

\section{Di-tert-Butyl-4-(2-(3-(4-hexylphenyl)ureido)benzyl)-1,4,7,10-tetraazacyclododecane-1,7-dicarboxylate}

(6b). A solution of compound $\mathbf{3 b}(0.319 \mathrm{~g}, 0.925 \mathrm{mmol})$ in acetonitrile $(50 \mathrm{~mL})$ was added dropwise to a suspension of compound $5(2.000 \mathrm{~g}, 4.627 \mathrm{mmol})$ and potassium carbonate $(1.292 \mathrm{~g}, 9.255 \mathrm{mmol})$ in acetonitrile $(100 \mathrm{~mL})$ and stirred at room temperature for $16 \mathrm{~h}$. The suspension was filtered and the filtrate concentrated to dryness. The residue was extracted with chloroform $(5 \times 50 \mathrm{~mL})$ and water $(25 \mathrm{~mL})$, the organic layer combined and dried over anhydrous $\mathrm{Na}_{2} \mathrm{SO}_{4}$, and the solvent evaporated under reduced pressure. The resulting oil was purified on a CombiFlash RF-200, using a 12 g-silica gel column and $\mathrm{CH}_{2} \mathrm{Cl}_{2} / \mathrm{MeOH}$ as eluent (from 0 to $5 \%$ of methanol; the desired compound eluted from 1.5 to $3 \%$ ) to give pure product $\mathbf{6 b}$ as a white foam $(0.436 \mathrm{~g}, 69 \%) .{ }^{1} \mathrm{H}$ NMR $\left(500 \mathrm{MHz}, \mathrm{CDCl}_{3}, 298 \mathrm{~K}\right): \delta 12.10$ (s), 11.35 (s), $9.72(\mathrm{~s}), 9.52(\mathrm{~s}), 9.18(\mathrm{~s}), 9.04(\mathrm{~s}), 8.87(\mathrm{~s}), 7.95-7.88(\mathrm{~m}), 7.48\left(\mathrm{~d},{ }^{3} J=8.0 \mathrm{~Hz}\right), 7.32(\mathrm{~m}), 7.07\left(\mathrm{~d},{ }^{3} J=8.4\right.$ Hz), 7.03-6.97 (m), 4.28 (m), 4.15 (s), 3.97 (m), 3.69-2.64 (m), $2.53(\mathrm{~m}), 1.57$ (m), 1.44-1.42 (m), $1.29(\mathrm{~m})$, $0.87(\mathrm{~m}) .{ }^{13} \mathrm{C}$ NMR $\left(125.8 \mathrm{MHz}, \mathrm{CDCl}_{3}, 298 \mathrm{~K}\right): \delta 155.6,155.4,154.3,154.0,138.6,137.2,137.0,131.6$, 131.5, 129.3, 128.8, 125.5, 123.6, 119.1, 81.8, 81.6, 81.4, 55.9, 53.9, 50.0, 48.9, 48.8, 48.4, 48.1, 47.4, 35.5, 31.9, 31.7, 29.1, 28.5, 22.8, 14.2. MS-ESI ${ }^{+}, m / z(\% B P I):[6 \mathbf{b}+\mathbf{H}]^{+}, 681.5(100 \%)$. Elem. Anal. Calcd for $\mathrm{C}_{38} \mathrm{H}_{60} \mathrm{~N}_{6} \mathrm{O}_{5}: \mathrm{C}, 67.0 ; \mathrm{H}, 8.9 ; \mathrm{N}, 12.3 \%$. Found: C, 66.7; H, 8.9; N, 12.0\%. IR: $3271 v(\mathrm{~N}-\mathrm{H}), 3120$ $2855 v(\mathrm{C}-\mathrm{H}), 1693 v(\mathrm{C}=\mathrm{O}), 1605,1588,1478,1453 v(\mathrm{C}=\mathrm{C}), 1538 \delta(\mathrm{N}-\mathrm{H}), 1155 v_{\mathrm{a}}(\mathrm{N}-\mathrm{C}), 751 \gamma(\mathrm{C}-\mathrm{H}) \mathrm{cm}^{-1}$.

\section{Di-tert-Butyl-4-(4-(tert-butyl)benzyl)-10-(2-(3-(4-hexylphenyl)ureido)benzyl)-1,4,7,10-}

tetraazacyclododecane-1,7-dicarboxylate (7b).A solution of 1-(bromomethyl)-4-(tert-butyl)benzene (0.179 $\mathrm{mL}, 0.946 \mathrm{mmol})$, compound $\mathbf{6 b}(0.429 \mathrm{~g}, 0.630 \mathrm{mmol}), N, N$-diisopropylethylamine $(0.222 \mathrm{~mL}, 1.261$ mmol) and a catalytic amount of KI in acetonitrile $(50 \mathrm{~mL})$ was heated to reflux with stirring for $16 \mathrm{~h}$. The resulting solution was filtered while hot and the filtrate concentrated to dryness. The residue was extracted 
with chloroform $(5 \times 25 \mathrm{~mL})$ and water $(15 \mathrm{~mL})$, the organic layer combined and dried over anhydrous $\mathrm{Na}_{2} \mathrm{SO}_{4}$, and the solvent evaporated under reduced pressure. The resulting oil was purified on a CombiFlash RF-200, using a 12 g-silica gel column and Hex/EtOAc as eluent (from 0 to $100 \%$ of ethyl acetate; the desired compound eluted from 20 to $50 \%)$ to give pure product $7 \mathbf{b}$ as a pale brown foam $(0.275 \mathrm{~g}, 53 \%)$. ${ }^{1} \mathrm{H}$ NMR (500 MHz, $\left.\mathrm{CDCl}_{3}, 298 \mathrm{~K}\right): \delta 9.35$ (s), 8.87 (s), 8.78 (s), $7.89\left(\mathrm{~d},{ }^{3} J=8.0 \mathrm{~Hz}\right), 7.48$ (d, $\left.{ }^{3} J=7.8 \mathrm{~Hz}\right)$, $7.35\left(\mathrm{~d},{ }^{3} \mathrm{~J}=8.2 \mathrm{~Hz}\right), 7.31(\mathrm{~m}), 7.26(\mathrm{~m}), 7.21(\mathrm{~m}), 7.17-7.13(\mathrm{~m}), 7.07\left(\mathrm{~d},{ }^{3} J=8.4 \mathrm{~Hz}\right), 6.93(\mathrm{~m}), 3.72(\mathrm{~m})$, 3.59-2.65 (m), $2.54(\mathrm{~m}), 1.58(\mathrm{~m}), 1.48-1.40(\mathrm{~m}), 1.31(\mathrm{~s}), 1.30(\mathrm{~m}), 1.22(\mathrm{~s}), 0.88(\mathrm{~m}) .{ }^{13} \mathrm{C}$ NMR $(125.8$ $\left.\mathrm{MHz}, \mathrm{CDCl}_{3}, 298 \mathrm{~K}\right): \delta 156.9,156.0,154.1,150.5,149.8,139.8,137.9,136.6,135.3,132.3,130.1,128.7$, $128.3,127.2,125.3,125.2,125.2,125.1,122.9,122.5,119.2,80.8,80.1,79.6,60.4,56.7,56.3,55.1,53.5$, 52.8, 51.2, 48.8, 47.9, 46.0, 45.2, 35.5, 34.6, 31.9, 31.8, 31.5, 31.5, 29.1, 28.7, 28.6, 28.5, 22.8, 14.3. MS$\mathrm{ESI}^{+}, m / z$ (\%BPI): $[7 \mathbf{b}+\mathrm{H}]^{+}, 827.6(100 \%)$. Elem. Anal. Calcd for $\mathrm{C}_{49} \mathrm{H}_{74} \mathrm{~N}_{6} \mathrm{O}_{5}: \mathrm{C}, 71.2 ; \mathrm{H}, 9.0 ; \mathrm{N}, 10.2 \%$. Found: C, 71.5; H, 8.9; N, 9.4\%. IR: $3336 v(\mathrm{~N}-\mathrm{H}), 2961-2800 v(\mathrm{C}-\mathrm{H}), 1688,1672 v(\mathrm{C}=\mathrm{O}), 1590,1477$, $1451 v(\mathrm{C}=\mathrm{C}), 1529 \delta(\mathrm{N}-\mathrm{H}), 1151 v_{\mathrm{a}}(\mathrm{N}-\mathrm{C}) \mathrm{cm}^{-1}$.

\section{1-(2-((7-(4-(tert-Butyl)benzyl)-1,4,7,10-tetraazacyclododecan-1-yl)methyl)phenyl)-3-(4-}

hexylphenyl)urea $\left(\mathbf{L}^{4}\right)$. A solution of compound $\mathbf{7 b}(0.236 \mathrm{~g}, 0.285 \mathrm{mmol})$ and trifluoroacetic acid $(5 \mathrm{~mL})$ in chloroform $(5 \mathrm{~mL})$ was stirred at room temperature for $16 \mathrm{~h}$. The solvent was removed by rotary evaporation and the residue was dissolved in chloroform $(30 \mathrm{~mL})$. The acid in excess was neutralized with an aqueous solution of $\mathrm{NaOH} 1 \mathrm{M}$ and the organic layer washed with distilled water $(2 \times 15 \mathrm{~mL})$. The organic phase was dried over anhydrous $\mathrm{Na}_{2} \mathrm{SO}_{4}$, and the solvent evaporated under reduced pressure to give pure product $\mathbf{L}^{4}$ as a brown oil which became a solid after remaining under vacuum for several days $(0.178 \mathrm{~g}, 100 \%)$. ${ }^{1} \mathrm{H}$ NMR $\left(500 \mathrm{MHz}, \mathrm{CDCl}_{3}, 298 \mathrm{~K}\right): \delta 9.63(\mathrm{~s}, 1 \mathrm{H}, \mathrm{H} 21), 8.21(\mathrm{~s}, 1 \mathrm{H}, \mathrm{H} 19), 8.06(\mathrm{~m}, 1 \mathrm{H}, \mathrm{H} 17), 7.51\left(\mathrm{~d}, 2 \mathrm{H}, \mathrm{H} 23,{ }^{3} J=\right.$ $8.5 \mathrm{~Hz}), 7.27$ (m, H16), $7.21\left(\mathrm{~d}, 2 \mathrm{H}, \mathrm{H} 4,{ }^{3} \mathrm{~J}=8.3 \mathrm{~Hz}\right), 7.06$ (m, 1H, H14), 7.01 (d, 2H, H24, $\left.{ }^{3} \mathrm{~J}=8.5 \mathrm{~Hz}\right)$, 6.95 (m, 1H, H15), 6.89 (d, 2H, H5, ${ }^{3} \mathrm{~J}=8.2 \mathrm{~Hz}$ ), 3.71 (s, 2H, H12), 3.45 (s, 2H, H7), 2.61 (s, H11), 2.532.34 (m, H8, H9 and H10), 1.49 (m, 2H, H27), 1.26 (m, H1, H28, H29 and H30), $0.86(\mathrm{~m}, 3 \mathrm{H}, \mathrm{H} 31) .{ }^{13} \mathrm{C}$ NMR $\left(125.8 \mathrm{MHz}, \mathrm{CDCl}_{3}, 298 \mathrm{~K}\right): \delta 154.5 \mathrm{C} 20,150.3 \mathrm{C} 3,138.9 \mathrm{C} 18,137.6 \mathrm{C} 22,136.9 \mathrm{C} 25,134.5 \mathrm{C} 6$, 131.4 C14, 128.8 C16, 128.8 C24, 128.7 C5, 127.3 C13, 125.3 C4, 122.9 C15, 122.8 C17, 118.9 C23, 61.3 C12, 59.5 C7, 52.3 C11, 50.5 C8 and C9, 47.5 C10, 35.3 C26, 34.5 C2, 31.8 C27, 31.8 C28, 31.4 C1, 29.1 C29, $22.7 \mathrm{C} 30,14.2 \mathrm{C} 31 . \mathrm{MS}_{\mathrm{ESI}}{ }^{+}, \mathrm{m} / z(\% \mathrm{BPI}):\left[\mathbf{L}^{4}+\mathrm{H}\right]^{+}, 627.5(100 \%)$. Elem. Anal. Calcd for $\mathrm{C}_{39} \mathrm{H}_{58} \mathrm{~N}_{6} \mathrm{O}: \mathrm{C}, 74.7 ; \mathrm{H}, 9.3$; N, 13.4\%. Found: C, 75.3; H, 9.3; N, 13.2\%. IR: $3320-3187 v(\mathrm{~N}-\mathrm{H}), 3120$ $2819 v(\mathrm{C}-\mathrm{H}), 1702 v(\mathrm{C}=\mathrm{O}), 1611,1588,1448 v(\mathrm{C}=\mathrm{C}), 749 \gamma(\mathrm{C}-\mathrm{H}) \mathrm{cm}^{-1}$.

General procedure for the preparation of $\left[\mathrm{ML}^{3} \mathrm{Cl}_{2}\right],\left[\mathrm{ML}^{3}\left(\mathrm{SO}_{4}\right)\right]$ and $\left[\mathrm{ML}^{3}\left(\mathrm{NO}_{2}\right)_{2}\right](\mathrm{M}=\mathrm{Cu}$ or $\mathrm{Zn})$

A solution of $\mathrm{MCl}_{2}$ or hydrated $\mathrm{M}\left(\mathrm{NO}_{3}\right)_{2}$ or $\mathrm{M}\left(\mathrm{SO}_{4}\right)(0.085 \mathrm{mmol}, \mathrm{M}=\mathrm{Cu}$ or $\mathrm{Zn})$ in methanol $(2 \mathrm{~mL})$ was added to a solution of $\mathbf{L}^{3}(0.050 \mathrm{~g}, 0.085 \mathrm{mmol})$ in methanol $(5 \mathrm{~mL})$. The mixture was stirred at room temperature for $16 \mathrm{~h}$, and the precipitate formed was isolated by filtration, washed with methanol $(2 \mathrm{~mL})$ and diethyl ether $(2 \mathrm{~mL})$ and dried under vacuum. In some cases an additional purification step was required to remove metal salt impurities: the solvent was evaporated under reduced pressure and the precipitate dissolved in chloroform $(5 \mathrm{~mL})$; the solution was then filtered and the filtrate concentrated to dryness. The solid was treated with diethyl ether $(5 \mathrm{~mL})$, filtrated and dried under vacuum.

$\left[\mathrm{CuL}^{3} \mathbf{C l}_{2}\right] \cdot \mathbf{3 M e O H}$. Dark green solid. Yield: $0.050 \mathrm{~g}, 71 \%$. MS-ESI ${ }^{+}, \mathrm{m} / \mathrm{z}(\% \mathrm{BPI}):\left[\mathrm{Cu}\left(\mathbf{L}^{3}\right) \mathrm{Cl}\right]^{+}, 685.3$ $(15 \%) ; \quad\left[\mathrm{Cu}\left(\mathbf{L}^{3}-\mathbf{H}\right)\right]^{+}, \quad 649.3 \quad(100 \%) ; \quad\left[\mathrm{Cu}\left(\mathbf{L}^{3}\right)\right]^{2+}, \quad 325.2 \quad(10 \%)$. Elem. Anal. Calcd for $\mathrm{C}_{33} \mathrm{H}_{45} \mathrm{Cl}_{2} \mathrm{CuN}_{7} \mathrm{O}_{3} \cdot 3 \mathrm{MeOH}: \mathrm{C}, 52.8 ; \mathrm{H}, 7.0 ; \mathrm{N}, 12.0 \%$. Found: C, 52.9; H, 6.5; N, 11.6\%. $\Lambda_{\mathrm{M}}(\mathrm{MeOH}$, $\left.10^{-3} \mathrm{M}, 25^{\circ} \mathrm{C}\right): 89.1 \mathrm{~cm}^{2} \Omega^{-1} \mathrm{~mol}^{-1}(1: 1$ electrolyte). IR: $3187 v(\mathrm{~N}-\mathrm{H}), 3120-2870 v(\mathrm{C}-\mathrm{H}), 1695 v(\mathrm{C}=\mathrm{O})$, $1588 v(\mathrm{C}=\mathrm{C}), 1524 v_{\mathrm{a}}\left(\mathrm{NO}_{2}\right), 1345 v_{\mathrm{s}}\left(\mathrm{NO}_{2}\right), 736 \gamma(\mathrm{C}-\mathrm{H}) \mathrm{cm}^{-1}$. UV/vis diffuse reflectance spectroscopy: 678 nm.

$\left[\mathrm{CuL}^{3}\left(\mathrm{NO}_{3}\right)_{2}\right] \cdot \mathbf{0 . 5} \mathrm{CHCl}_{3} \cdot \mathbf{2 M e O H}$. Dark blue solid. Yield: $0.045 \mathrm{~g}, 59 \%$. Elem. Anal. Calcd for $\mathrm{C}_{33} \mathrm{H}_{45} \mathrm{CuN}_{9} \mathrm{O}_{9} \cdot 0.5 \mathrm{CHCl}_{3} \cdot 2 \mathrm{MeOH}: \mathrm{C}, 47.4 ; \mathrm{H}, 6.0 ; \mathrm{N}, 14.0 \%$. Found: C, 47.7; H, 6.1; N, 13.6. $\Lambda_{\mathrm{M}}(\mathrm{MeOH}$, 
$\left.10^{-3} \mathrm{M}, 25^{\circ} \mathrm{C}\right): 173.1 \mathrm{~cm}^{2} \Omega^{-1} \mathrm{~mol}^{-1}$ (2 : 1 electrolyte). IR: $3230 v(\mathrm{~N}-\mathrm{H}), 3120-2870 v(\mathrm{C}-\mathrm{H}), 1714 v(\mathrm{C}=\mathrm{O})$, $1526 v_{\mathrm{a}}\left(\mathrm{NO}_{2}\right), 1317 v_{\mathrm{a}}(\mathrm{N}-\mathrm{O}), 735 \delta_{\mathrm{a}}(\mathrm{O}-\mathrm{N}-\mathrm{O}) \mathrm{cm}^{-1}$. UV/vis diffuse reflectance spectroscopy: $594 \mathrm{~nm}$.

$\left[\mathbf{C u L}^{3}\left(\mathbf{S O}_{4}\right)\right] \cdot \mathbf{1 . 5 H} \mathbf{O}$ O. Light blue solid. Yield: $0.039 \mathrm{~g}, 59 \%$. MS-ESI ${ }^{+}, m / z(\% \mathrm{BPI}):\left[\mathrm{Cu}\left(\mathbf{L}^{3}-\mathrm{H}\right)\right]^{+}, 649.3$ (100\%); $\left[\mathrm{Cu}\left(\mathbf{L}^{3}\right)\right]^{2+}, 325.2$ (33\%). Elem. Anal. Calcd for $\mathrm{C}_{33} \mathrm{H}_{45} \mathrm{CuN}_{7} \mathrm{O}_{7} \mathrm{~S} \cdot 1.5 \mathrm{H}_{2} \mathrm{O}: \mathrm{C}, 51.2 ; \mathrm{H}, 6.3 ; \mathrm{N}, 12.7 \%$. Found: C, 51.1; H, 6.2; N, 12.5\%. $\Lambda_{\mathrm{M}}\left(\mathrm{MeOH}, 10^{-3} \mathrm{M}, 25{ }^{\circ} \mathrm{C}\right): 7.8 \mathrm{~cm}^{2} \Omega^{-1} \mathrm{~mol}^{-1}$ (non-electrolyte). IR: $3223 v(\mathrm{~N}-\mathrm{H}), 3130-2870 v(\mathrm{C}-\mathrm{H}), 1711 v(\mathrm{C}=\mathrm{O}), 1589 v(\mathrm{C}=\mathrm{C}), 1545 \delta(\mathrm{N}-\mathrm{H}), 1525 v_{\mathrm{a}}\left(\mathrm{NO}_{2}\right), 1350 v_{\mathrm{s}}\left(\mathrm{NO}_{2}\right)$, $1106,1088,1026 v_{\mathrm{a}}(\mathrm{S}-\mathrm{O}), 739 \gamma(\mathrm{C}-\mathrm{H}), 616,597 \delta_{\mathrm{a}}(\mathrm{O}-\mathrm{S}-\mathrm{O}) \mathrm{cm}^{-1}$. UV/vis diffuse reflectance spectroscopy: $657 \mathrm{~nm}$. Slow evaporation of a solution of the complex in a chloroform/methanol mixture provided dark blue single crystals suitable for X-ray diffraction analysis.

$\left[\mathrm{CuL}^{3}\left(\mathbf{C l O}_{4}\right)_{2}\right] \cdot \mathbf{2 H}_{2} \mathbf{O}$. Dark green solid. Yield: $0.067 \mathrm{~g}, 88 \%$. MS-ESI ${ }^{+}, \mathrm{m} / z(\% \mathrm{BPI}):\left[\mathrm{Cu}\left(\mathbf{L}^{3}\right)\right]^{+}, 649.3(1 \%)$. Elem. Anal. Calcd for $\mathrm{C}_{33} \mathrm{H}_{45} \mathrm{Cl}_{2} \mathrm{CuN}_{7} \mathrm{O}_{11} \cdot 2 \mathrm{H}_{2} \mathrm{O}: \mathrm{C}, 44.7 ; \mathrm{H}, 5.6 ; \mathrm{N}, 11.1 \%$. Found: $\mathrm{C}, 44.4 ; \mathrm{H}, 4.5 ; \mathrm{N}$, 10.9\%. $\Lambda_{\mathrm{M}}\left(\mathrm{MeOH}, 10^{-3} \mathrm{M}, 25{ }^{\circ} \mathrm{C}\right): 163 \mathrm{~cm}^{2} \Omega^{-1} \mathrm{~mol}^{-1}(2: 1$ electrolyte). IR: 3354, $3279 v(\mathrm{~N}-\mathrm{H}), 3090$ $2860 v(\mathrm{C}-\mathrm{H}), 1529 v_{\mathrm{a}}\left(\mathrm{NO}_{2}\right), 1349 v_{\mathrm{s}}\left(\mathrm{NO}_{2}\right), 1076 v_{\mathrm{a}}(\mathrm{Cl}-\mathrm{O}), 621 \delta_{\mathrm{a}}(\mathrm{O}-\mathrm{Cl}-\mathrm{O}) \mathrm{cm}^{-1}$. UV/vis diffuse reflectance spectroscopy: $589 \mathrm{~nm}$.

$\left[\mathrm{ZnL}^{3} \mathbf{C l}_{2}\right] \cdot \mathbf{2 M e O H}$. Light brown solid. Yield: $0.053 \mathrm{~g}, 79 \%$. MS-ESI ${ }^{+}, \mathrm{m} / z$ (\%BPI): $\left[\mathrm{Zn}\left(\mathbf{L}^{3}-\mathrm{H}\right)\right]^{+}, 650.3$ (100\%). Elem. Anal. Calcd for $\mathrm{C}_{33} \mathrm{H}_{45} \mathrm{Cl}_{2} \mathrm{~N}_{7} \mathrm{O}_{3} \mathrm{Zn} \cdot 2 \mathrm{MeOH}$ : C, 53.3; H, 6.8; N, 12.4\%. Found: C, 53.3; $\mathrm{H}$, $6.5 ; \mathrm{N}, 12.2 \% . \Lambda_{\mathrm{M}}\left(\mathrm{MeOH}, 10^{-3} \mathrm{M}, 25{ }^{\circ} \mathrm{C}\right): 76.6 \mathrm{~cm}^{2} \Omega^{-1} \mathrm{~mol}^{-1}(1: 1$ electrolyte). IR: $3227 v(\mathrm{~N}-\mathrm{H}), 3130$ $2875 v(\mathrm{C}-\mathrm{H}), 1697 v(\mathrm{C}=\mathrm{O}), 1605,1588 v(\mathrm{C}=\mathrm{C}), 1524 v_{\mathrm{a}}\left(\mathrm{NO}_{2}\right), 1345 v_{\mathrm{s}}\left(\mathrm{NO}_{2}\right), 737 \gamma(\mathrm{C}-\mathrm{H}) \mathrm{cm}^{-1} .{ }^{1} \mathrm{H}$ NMR $\left(500 \mathrm{MHz}\right.$, dmso- $\left.d_{6}, 298 \mathrm{~K}\right): \delta 10.12(\mathrm{~s}), 9.70(\mathrm{~s}), 9.11(\mathrm{~s}), 8.97(\mathrm{~s}), 8.61(\mathrm{~s}), 8.57(\mathrm{~s}), 7.83-7.76(\mathrm{~m}), 7.58$ (m), 7.44-7.37 (m), 7.30-7.19 (m), $4.77(\mathrm{~s}), 3.98(\mathrm{~s}), 3.88(\mathrm{~s}), 3.83(\mathrm{~s}), 3.73(\mathrm{~s}), 3.15(\mathrm{~s}), 2.98(\mathrm{~m}), 2.76-2.65$ (m), 1.27 (s). ${ }^{13} \mathrm{C}$ NMR $\left(125.8 \mathrm{MHz}\right.$, dmso- $\left.d_{6}, 298 \mathrm{~K}\right): \delta 153.6,150.6,149.9,148.2,141.5,141.4,137.9$, 137.3, 132.7, 131.9, 131.1, 130.9, 130.1, 129.8, 129.7, 129.5, 129.3, 129.2, 129.0, 128.4, 128.1, 127.9, 127.4, $126.3,126.0,125.3,125.2,124.9,124.3,124.1,116.2,116.1,112.1,112.0,55.9,55.5,51.5,51.3,48.7,47.1$, $46.8,42.9,42.9,42.6,42.5,34.3,34.3,31.2,31.1$.

$\left[\mathbf{Z n L}^{3}\left(\mathbf{N O}_{3}\right)_{2}\right] \cdot \mathbf{C H C l}_{3}$. Light brown solid. Yield: $0.064 \mathrm{~g}, 84 \%$. MS-ESI ${ }^{+}, \mathrm{m} / z(\% \mathrm{BPI}):\left[\mathrm{Zn}\left(\mathbf{L}^{3}-\mathrm{H}\right)\right]^{+}, 650.3$ (100\%). Elem. Anal. Calcd for $\mathrm{C}_{33} \mathrm{H}_{45} \mathrm{~N}_{9} \mathrm{O}_{9} \mathrm{Zn} \cdot \mathrm{CHCl}_{3}: \mathrm{C}, 45.6 ; \mathrm{H}, 5.2 ; \mathrm{N}, 14.1 \%$. Found: $\mathrm{C}, 45.8 ; \mathrm{H}, 5.3 ; \mathrm{N}$, 13.4. $\Lambda_{\mathrm{M}}\left(\mathrm{MeOH}, 10^{-3} \mathrm{M}, 25^{\circ} \mathrm{C}\right): 133.5 \mathrm{~cm}^{2} \Omega^{-1} \mathrm{~mol}^{-1}$. IR: $3251 v(\mathrm{~N}-\mathrm{H}), 3120-2860 v(\mathrm{C}-\mathrm{H}), 1695 v(\mathrm{C}=\mathrm{O})$, $1601 v(\mathrm{C}=\mathrm{C}), 1525 v_{\mathrm{a}}\left(\mathrm{NO}_{2}\right), 1343,1323,1293 v_{\mathrm{a}}(\mathrm{N}-\mathrm{O}), 737 \delta_{\mathrm{a}}(\mathrm{O}-\mathrm{N}-\mathrm{O}) \mathrm{cm}^{-1} .{ }^{1} \mathrm{H}$ NMR $\left(500 \mathrm{MHz}\right.$, dmso- $d_{6}$, $298 \mathrm{~K}): \delta 9.70(\mathrm{~s}), 9.59(\mathrm{~s}), 8.79(\mathrm{~s}), 8.77(\mathrm{~s}), 8.60(\mathrm{~m}), 8.57(\mathrm{~m}), 7.82(\mathrm{~m}), 7.75(\mathrm{~m}), 7.57(\mathrm{~m}), 7.45-7.37$ (m), 7.29-7.21 (m), $4.77(\mathrm{~s}), 3.97(\mathrm{~s}), 3.84(\mathrm{~s}), 3.81(\mathrm{~s}), 3.73(\mathrm{~s}), 3.16(\mathrm{~s}), 3.04(\mathrm{~m}), 2.75(\mathrm{~m}), 2.56(\mathrm{~m}), 1.27$ (s). ${ }^{13} \mathrm{C}$ NMR (125.8 MHz, dmso- $\left.d_{6}, 298 \mathrm{~K}\right): \delta 153.6,153.6,150.8,150.0,148.2,141.4,141.4,137.9,137.1$, 132.6, 132.0, 131.0, 130.2, 130.1, 129.9, 129.6, 129.2, 129.0, 128.5, 128.1, 127.7, 127.5, 126.6, 126.1, 125.5, $125.3,125.2,124.6,124.4,124.3,116.3,116.3,112.2,112.1,55.6,55.2,51.2,50.7,48.9,47.1,46.8,42.8$, $42.8,42.6,42.5,34.4,34.3,31.2,31.2$. Slow diffusion of diethyl ether into a solution of the complex in an acetonitrile/methanol mixture gave pale yellow single crystals suitable for X-ray diffraction analysis.

$\left[\mathbf{Z n L}^{3}\left(\mathbf{S O}_{4}\right)\right]$. Light yellow solid. Yield: $0.042 \mathrm{~g}, 66 \%$. $\mathrm{MS}^{-E_{S S}}{ }^{+}, m / z(\% \mathrm{BPI}):\left[\mathrm{Zn}\left(\mathbf{L}^{3}-\mathrm{H}\right)\right]^{+}, 650.3(100 \%)$. Elem. Anal. Calcd for $\mathrm{C}_{33} \mathrm{H}_{45} \mathrm{~N}_{7} \mathrm{O}_{7} \mathrm{SZn}: \mathrm{C}, 52.9 ; \mathrm{H}, 6.1 ; \mathrm{N}, 13.1 \%$. Found: $\mathrm{C}, 52.6 ; \mathrm{H}, 6.0 ; \mathrm{N}$, $12.9 \% . \Lambda_{\mathrm{M}}\left(\mathrm{MeOH}, 10^{-3} \mathrm{M}, 25{ }^{\circ} \mathrm{C}\right)$ : the low solubility of this complex in methanol has prevented us from determining the conductivity value for this compound. IR: $3228 v(\mathrm{~N}-\mathrm{H}), 3130-2882 v(\mathrm{C}-\mathrm{H}), 1712 v(\mathrm{C}=\mathrm{O})$, $1590 v(\mathrm{C}=\mathrm{C}), 1550 \delta(\mathrm{N}-\mathrm{H}), 1529 v_{\mathrm{a}}\left(\mathrm{NO}_{2}\right), 1348 v_{\mathrm{s}}\left(\mathrm{NO}_{2}\right), 1024 v_{\mathrm{a}}(\mathrm{S}-\mathrm{O}), 611,593 \delta_{\mathrm{a}}(\mathrm{O}-\mathrm{S}-\mathrm{O}) \mathrm{cm}^{-1} . \delta_{\mathrm{H}}$ and $\delta_{\mathrm{C}}$ (solvent dmso- $d_{6}$ ): the low solubility of this complex in dmso- $d_{6}$ has prevented us from recording its ${ }^{1} \mathrm{H}$ and ${ }^{13} \mathrm{C}$ NMR spectra.

$\left[\mathrm{ZnL}^{3}\left(\mathrm{ClO}_{4}\right)_{2}\right] \cdot \mathbf{H}_{2} \mathbf{O}$. Light brown solid. Yield: $0.065 \mathrm{~g}, 88 \%$. MS-ESI ${ }^{+}, \mathrm{m} / \mathrm{z}(\% \mathrm{BPI}):\left[\mathrm{Zn}\left(\mathbf{L}^{3}-\mathrm{H}\right)\right]^{+}, 650.3$ (100\%). Elem. Anal. Calcd for $\mathrm{C}_{33} \mathrm{H}_{45} \mathrm{Cl}_{2} \mathrm{~N}_{7} \mathrm{O}_{11} \mathrm{Zn} \cdot \mathrm{H}_{2} \mathrm{O}$ : C, 45.6; H, 5.4; N, 11.3\%. Found: C, 45.4; H, 4.9; $\mathrm{N}, 11.2 \% . \Lambda_{\mathrm{M}}\left(\mathrm{MeOH}, 10^{-3} \mathrm{M}, 25{ }^{\circ} \mathrm{C}\right): 186.8 \mathrm{~cm}^{2} \Omega^{-1} \mathrm{~mol}^{-1}(2: 1$ electrolyte). IR: $3361-3288 v(\mathrm{~N}-\mathrm{H})$, 
3090-2870v(C-H), $1528 v_{\mathrm{a}}\left(\mathrm{NO}_{2}\right), 1348 v_{\mathrm{s}}\left(\mathrm{NO}_{2}\right), 1069 v_{\mathrm{a}}(\mathrm{Cl}-\mathrm{O}), 621 \delta_{\mathrm{a}}(\mathrm{O}-\mathrm{Cl}-\mathrm{O}) \mathrm{cm}^{-1} .{ }^{1} \mathrm{H}$ NMR $(500 \mathrm{MHz}$, dmso- $\left.d_{6}, 298 \mathrm{~K}\right): \delta 9.38(\mathrm{~s}), 8.56(\mathrm{~m}), 8.54(\mathrm{~m}), 8.16(\mathrm{~s}), 7.87(\mathrm{~m}), 7.84(\mathrm{~m}), 7.75(\mathrm{~m}), 7.66(\mathrm{~m}), 7.58(\mathrm{~m})$, $7.42(\mathrm{~m}), 7.33(\mathrm{~m}), 7.26(\mathrm{~m}), 7.02(\mathrm{~m}), 4.77(\mathrm{~s}), 3.98(\mathrm{~s}), 3.85(\mathrm{~s}), 3.04(\mathrm{~s}), 2.86(\mathrm{~s}), 2.72(\mathrm{~m}), 1.28(\mathrm{~m}) .{ }^{13} \mathrm{C}$ NMR (125.8 MHz, dmso- $\left.d_{6}, 298 \mathrm{~K}\right): \delta 157.0,153.7,150.9,150.7,148.2,147.9,146.8,143.4,141.3,137.8$, $132.7,132.5,131.0,130.9,130.2,130.1,129.6,129.4,129.3,129.0,127.9,127.4,126.1,126.0,125.6,125.4$, $125.3,125.0,124.5,122.2,116.5,114.9,112.8,112.3,56.0,55.7,55.3,50.9,48.9,48.8,42.8,42.7,34.4$, $31.2,31.2$.

\section{$\underline{\text { Solvent extraction experiments }}$}

Inductively coupled plasma optical emission spectroscopy (ICP-OES) analysis was performed on a Perkin Elmer Optima 5300DV spectrometer and standards were purchased from Alfa Aesar. Organic ICP-OES samples were made up by evaporating $1 \mathrm{~mL}$ samples of the organic phase and re-dissolving in $10 \mathrm{~mL}$ butan1-ol. The measurements of $\mathrm{pH}$ were carried out using a Sartorius PP-50 pH meter. All extractions were performed by vigorously stirring solutions with magnetic stirring bars in sealed $20 \mathrm{~mL}$ vials for $16 \mathrm{~h}$ at room temperature (see solvent extraction details for different experiments, ESI $\dagger$ ).

Table 4. Crystal data and refinement details for $\mathbf{L}^{3}$, $\left[\mathrm{CuL}^{3}\left(\mathrm{SO}_{4}\right)\right] \cdot \mathrm{MeOH},\left[\mathrm{ZnL}^{3}\left(\mathrm{NO}_{3}\right)\right]\left(\mathrm{NO}_{3}\right) \cdot 0.75 \mathrm{MeOH}$ and $\left[\mathrm{CuL}^{\mathbf{1}}\left(\mu-\mathrm{SO}_{4}\right)\right]_{2} \cdot \mathrm{C}_{6} \mathrm{H}_{6} \mathrm{~N}_{2} \mathrm{O}_{2}$

\begin{tabular}{|c|c|c|c|c|}
\hline & $\mathbf{L}^{3}$ & {$\left[\mathrm{CuL}^{3}\left(\mathrm{SO}_{4}\right)\right] \cdot \mathrm{MeOH}$} & {$\left[\mathrm{ZnL} \mathbf{L}^{3}\left(\mathrm{NO}_{3}\right)\right] \mathrm{NO}_{3} \cdot 0.75 \mathrm{MeOH}$} & {$\left[\mathrm{CuL}^{\mathbf{1}}\left(\mu-\mathrm{SO}_{4}\right)\right]_{2} \cdot \mathrm{C}_{6} \mathrm{H}_{6} \mathrm{~N}_{2} \mathrm{O}_{2}$} \\
\hline Formula & $\mathrm{C}_{33} \mathrm{H}_{45} \mathrm{~N}_{7} \mathrm{O}_{3}$ & $\mathrm{C}_{34} \mathrm{H}_{49} \mathrm{CuN}_{7} \mathrm{O}_{8} \mathrm{~S}$ & $\mathrm{C}_{33.75} \mathrm{H}_{49} \mathrm{~N}_{9} \mathrm{O}_{9.75} \mathrm{Zn}$ & $\mathrm{C}_{64} \mathrm{H}_{60} \mathrm{Cu}_{2} \mathrm{~N}_{16} \mathrm{O}_{18} \mathrm{~S}_{2}$ \\
\hline MW & 587.76 & 779.40 & 801.18 & 1532.48 \\
\hline Crystal system & Monoclinic & Triclinic & Monoclinic & Triclinic \\
\hline Space group & $P 2_{1} / c$ & $P \overline{1}$ & $C 2 / c$ & $P \overline{1}$ \\
\hline$T / \mathrm{K}$ & $100(2)$ & $100(2)$ & $100(2)$ & $100(2)$ \\
\hline$a / \AA$ & 14.901(1) & $10.1147(4)$ & $37.519(1)$ & $8.9322(4)$ \\
\hline$b / \AA$ & $11.9675(8)$ & $10.8086(4)$ & $10.8462(3)$ & $13.2792(6)$ \\
\hline$c / \AA$ & $17.987(1)$ & $16.8713(7)$ & $22.2476(7)$ & $14.2039(6)$ \\
\hline$\alpha /^{\circ}$ & 90 & $76.478(2)$ & 90 & $86.497(2)$ \\
\hline$\beta /^{\circ}$ & $92.980(5)$ & $78.801(2)$ & $122.529(2)$ & $88.233(2)$ \\
\hline$\gamma /{ }^{\circ}$ & 90 & $79.307(2)$ & 90 & $72.795(2)$ \\
\hline$V / \AA^{3}$ & $3203.1(4)$ & $1740.1(1)$ & $7633.1(4)$ & $1606.2(1)$ \\
\hline$F(000)$ & 1264 & 822 & 3372 & 790 \\
\hline$Z$ & 4 & 2 & 8 & 1 \\
\hline$\lambda, \AA \stackrel{\AA}{\left(\mathrm{MoK}_{\alpha}\right)}$ & 0.71073 & 0.71073 & 0.71073 & 0.71073 \\
\hline$D_{\text {cald }} / \mathrm{g} \mathrm{cm}^{-3}$ & 1.219 & 1.488 & 1.394 & 1.584 \\
\hline$\mu / \mathrm{mm}^{-1}$ & 0.080 & 0.751 & 0.710 & 0.815 \\
\hline$\theta$ range $/^{\circ}$ & $2.04-28.33$ & $2.07-28.45$ & $1.99-28.38$ & $2.45-26.52$ \\
\hline$R_{\text {int }}$ & 0.0672 & 0.0477 & 0.0802 & 0.0361 \\
\hline Reflections measured & 56699 & 35120 & 65309 & 27518 \\
\hline Unique reflections & 7961 & 8657 & 9555 & 6573 \\
\hline Reflections observed & 5521 & 7031 & 6540 & 5552 \\
\hline GOF on $F^{2}$ & 1.033 & 1.030 & 1.048 & 1.047 \\
\hline$R_{1}^{a}$ & 0.0483 & 0.0385 & 0.0542 & 0.0304 \\
\hline $\mathrm{w} R_{2}^{b}$ & 0.1231 & 0.1036 & 0.1637 & 0.0765 \\
\hline Largest diff. peak \& hole/e $\AA^{-3}$ & 0.382 and -0.258 & 0.886 and -0.538 & 1.435 and -0.746 & 0.408 and -0.406 \\
\hline CCDC deposition number & 1525437 & 1525438 & 1525435 & 1525436 \\
\hline
\end{tabular}

${ }^{a} R_{1}=\sum|| F_{\mathrm{o}}|-| F_{\mathrm{c}}|| \sum\left|F_{\mathrm{o}}\right|{ }^{b} \mathrm{w} R_{2}$ (all data) $=\left\{\sum\left[\mathrm{w}\left(\left.|| F_{\mathrm{o}}\right|^{2}-\left|F_{\mathrm{c}}\right|^{2}\right)^{2}\right] / \sum\left[\mathrm{w}\left(F_{\mathrm{o}}{ }^{4}\right)\right]\right\}^{1 / 2}$ 


\section{$\underline{\text { X-ray diffraction studies }}$}

Single crystals were obtained from solutions of the isolated compounds, as described above. Three dimensional X-ray data were collected on a BRUKER-NONIUS X8 APEX KAPPA CCD diffractometer. Data were corrected for Lorentz and polarisation effects and for absorption by semiempirical methods ${ }^{49}$ based on symmetry-equivalent reflections. Complex scattering factors were taken from the SHELXL (version 2014/7 or 2016/6 only for the Zn complex) programs ${ }^{50}$ running under the WinGX program system $^{51}$ as implemented on a Pentium computer. The structures were solved either by Patterson methods with DIRDIF2008, ${ }^{52}$ except that of $\mathbf{L}^{3}$, which was solved by direct methods using the SHELXL programs. ${ }^{50}$ All structures were refined by full-matrix least-squares on $F^{2}$. For the four compounds all hydrogen atoms were included in calculated positions and refined in riding mode, except some hydrogen atoms involved in hydrogen bonding that were refined freely $\left(\mathrm{H} 2 \mathrm{~N}, \mathrm{H} 3 \mathrm{~N}, \mathrm{H} 5 \mathrm{~N}\right.$ H6N in $\mathbf{L}^{3} ; \mathrm{H} 3 \mathrm{~N}$ in $\left[\mathrm{CuL}^{3}\left(\mathrm{SO}_{4}\right)\right] \cdot \mathrm{MeOH}$ and $\mathrm{H} 2 \mathrm{~A}, \mathrm{H} 2 \mathrm{~B}, \mathrm{H} 3 \mathrm{~N}, \mathrm{H} 5 \mathrm{~N}$ and $\mathrm{H} 6 \mathrm{~N}$ in $\left[\mathrm{ZnL}^{3}\left(\mathrm{NO}_{3}\right)\right]\left(\mathrm{NO}_{3}\right) \cdot 0.75 \mathrm{MeOH}$ and $\mathrm{H} 2 \mathrm{~N}$ and $\mathrm{H} 3 \mathrm{~N}$ in $\left.\left[\mathrm{CuL}^{\mathbf{1}}\left(\mu-\mathrm{SO}_{4}\right)\right]_{2} \cdot \mathrm{C}_{6} \mathrm{H}_{6} \mathrm{~N}_{2} \mathrm{O}_{2}\right)$. The crystal structure of $\left[\mathrm{CuL}^{3}\left(\mathrm{SO}_{4}\right)\right] \cdot \mathrm{MeOH}$ shows positional disorder for the sulfate anion with an occupation factor of 0.77(2) for the atoms labelled as A. The crystal of $\left[\mathrm{ZnL}^{3}\left(\mathrm{NO}_{3}\right)\right]\left(\mathrm{NO}_{3}\right) \cdot 0.75 \mathrm{MeOH}$ also shows positional disorder affecting one of the nitrate anions, the tertbutyl group and the distal part of the urea moiety. The occupancy factors for the positions labelled as A for the nitrate anion were 0.574(6) and 0.60(2) for the tert-butyl group. The methanol molecules show occupancy factors of 0.430(4) (1S) and 0.320(4) (2S). 182 least-squares restrains had to be imposed to reach convergence. Refinement converged with anisotropic displacement parameters for all non-hydrogen atoms for all four crystals. Crystal data and details on data collection and refinement are summarised in Table 4.

CCDC $1525435-1525438$ contain the supplementary crystallographic data for this paper.

\section{Acknowledgments}

The authors thank Xunta de Galicia (EM 2012/088) and (CN-2012/011) for generous financial support and Centro de Supercomputación de Galicia (CESGA) for providing the computer facilities. I. C.-B. thanks Ministerio de Educación y Ciencia (FPU program) for a predoctoral fellowship.

\section{Notes and references}

1. (a) J. R. Turkington, P. J. Bailey, J. B. Love, A. M. Wilson and P. A. Tasker, Chem. Commun., 2013, 49, 1891; (b) A. M. Wilson, P. J. Bailey, P. A. Tasker, J. R. Turkington, R. A. Grant and J. B. Love, Chem. Soc. Rev., 2014, 43, 123; (c) J. Szymanowski, Hydroxyoximes and Copper Hydrometallurgy, CRC Press, 1990.

2. M. Cox, in Solvent Extraction Principles and Practice, ed. J. Rydberg, M. Cox, C. Musikas and G. R. Choppin, Marcel Dekker, Inc, New York, 2nd edn, 2004, ch. 11.

3. D. S. Flett, J. Organomet. Chem., 2005, 690, 2426.

4. M. K. Jha, V. Kumar and R. J. Singh, Solvent Extr. Ion Exch., 2002, 20, 389.

5. Comprehensive Coordination Chemistry II, ed. P. A. Tasker, P. G. Plieger and L. C. West, Elsevier Ltd., Oxford, 2004.

6. Y. Marcus, Ion Properties, Marcel Dekker, New York, 1997. 
7. C. J. Fowler, T. J. Haverlock, B. A. Moyer, J. A. Shriver, D. E. Gross, M. Marquez, J. L. Sessler, M. A. Hossain and K. Bowman-James, J. Am. Chem. Soc., 2008, 130, 14386.

8. (a) J. M. Mahoney, K. A. Stucker, H. Jiang, I. Carmichael, N. R. Brinkmann, A. M. Beatty, B. C. Noll and B. D. Smith, J. Am. Chem. Soc., 2005, 127, 2922; (b) R. J. Ellis, J. Chartres, P. A. Tasker and K. C. Sole, Solvent Extr. Ion Exch., 2011, 29, 657.

9. (a) T. Lin, V. Gasperov, K. J. Smith, C. C. Tong and P. A. Tasker, Dalton Trans., 2010, 39, 9760; (b) G. W. Bates, J. E. Davidson, R. S. Forgan, P. A. Gale, D. K. Henderson, M. G. King, M. E. Light, S. J. Moore, P. A. Tasker and C. C. Tong,Supramol. Chem., 2012, 24, 117.

10. (a) L. Tjioe, A. Meininger, T. Joshi, L. Spiccia and B. Graham, Inorg. Chem., 2011, 50, 4327; (b) L. Tjioe, T. Joshi, C. M. Forsyth, B. Moubaraki, K. S. Murray, J. Brugger, B. Graham and L. Spiccia, Inorg. Chem., 2012, 51, 939.

11. (a) T. Guchhait, B. Barua, A. Biswas, B. Basak and G. Mani, Dalton Trans., 2015, 44, 9091; (b) I.W. Park, J. Yoo, S. Adhikari, J. S. Park, J. L. Sessler and C.-H. Lee, Chem. - Eur. J., 2012, 18, 15073; (c) I.-W. Park, J. Yoo, B. Kim, S. Adhikari, S. K. Kim, Y. Yeon, C. J. E. Haynes, J. L. Sutton, C. C. Tong, V. M. Lynch, J. L. Sessler, P. A. Gale and C.-H. Lee, Chem. - Eur. J., 2012, 18, 2514.

12. (a) T. K. Ghosh, R. Dutta and P. Ghosh, Inorg. Chem., 2016, 55, 3640; (b) M. Yamamura, J. Miyake, Y. Imamura and T. Nabeshima, Chem. Commun., 2011, 47, 6801.

13. V. Amendola, D. Esteban-Gómez, L. Fabrizzi, M. Licchelli, E. Monzani and F. Sancenon, Inorg. Chem., 2005, 44, 8690.

14. I. Carreira-Barral, T. Rodríguez-Blas, C. Platas-Iglesias, A. de Blas and D. Esteban-Gómez, Inorg. Chem., 2014, 53, 2554.

15. L. M. P. Lima, D. Esteban-Gómez, R. Delgado, C. Platas-Iglesias and R. Tripier, Inorg. Chem., 2012, 51, 6916.

16. R. D. Hancock, M. S. Shaikjee, S. M. Dobson and J. C. A. Boeyens, Inorg. Chim. Acta, 1988, 154, 229.

17. G. Anderegg, E. Hubmann, N. G. Podder and F. Wenk, Helv. Chim. Acta, 1977, 60, 123.

18. (a) C. V. Esteves, P. Lamosa, R. Delgado, J. Costa, P. Desorege, Y. Rousselin, C. Goze and F. Denat, Inorg. Chem., 2013, 52, 5138; (b) L. M. P. Lima, C. V. Esteves, R. Delgado, P. Hermann, J. Kotek, R. Sevcikova and P. Lubal, Eur. J. Inorg. Chem., 2012, 2533.

19. J. M. De León-Rodríguez, Z. Kovacs, A. C. Esqueda-Oliva and A. D. Miranda-Olvera, Tetrahedron Lett., 2006, 47, 6937.

20. (a) M. Woods, S. Aime, M. Botta, J. A. K. Howard, J. M. Moloney, M. Navet, D. Parker, M. Port and O. Rousseaux, J. Am. Chem. Soc., 2000, 122, 9781; (b) S. Aime, A. Barge, J. I. Bruce, M. Botta, J. A. K. Howard, J. M. Moloney, D. Parker, A. S. De Sousa and M. Woods, J. Am. Chem. Soc., 1999, 121, 5762; (c) A. Rodríguez-Rodríguez, Z. Garda, E. Ruscsak, D. Esteban-Gomez, A. de Blas, T. Rodríguez-Blas, L. M. P. Lima, M. Beyler, R. Tripier, G. Tircso and C. Platas-Iglesias, Dalton Trans., 2015, 44, 5017. 
21. (a) R. Martínez-Máñez and F. Sacenon, Chem. Rev., 2003, 103, 4419; (b) M. Regueiro-Figueroa, K. Djanashvili, D. Esteban-Gómez, A. de Blas, C. Platas-Iglesias and T. Rodríguez-Blas, Eur. J. Org. Chem., 2010, 3237.

22. (a) B. J. Hathaway, Struct. Bonding, 1973, 14, 49; (b) A. W. Addison, T. Nageswara-Rao, J. Reedijk, J. van Rijn and G. C. Verschoor, J. Chem. Soc., Dalton Trans., 1984, 1349.

23. (a) A. Carné-Sánchez, C. S. Bonnet, I. Imaz, J. Lorenzo, E. Tóth and D. Maspoch, J. Am. Chem. Soc., 2013, 135, 1771 ; (b) Y. Habata, M. Ikeda, A. K. Sah, K. Noto and S. Kuwahara, Inorg. Chem., 2013, 52, 11697; (c) C. V. Esteves, J. Madureira, L. M. P. Lima, P. Mateus, I. Bento and R. Delgado, Inorg. Chem., 2014, 53, 4371.

24. (a) J. K. Beattie, Acc. Chem. Res., 1971, 4, 253; (b) L. M. P. Lima, D. Esteban-Gómez, R. Delgado, C. Platas-Iglesias and R. Tripier, Inorg. Chem., 2012, 51, 6916.

25. (a) Z. Vargová, R. Gyepes, L. Arabuli, K. Györyová, P. Hermann and I. Lukes, Inorg. Chim. Acta, 2009, 362, 3860; (b) M. H. Salter, J. H. Reibenspies, S. B. Jones and R. D. Hancock, Inorg. Chem., 2005, 44, 2791; (c) M. Subat, A. S. Borovik and B. König, J. Am. Chem. Soc., 2004, 126, 3185; (d) E. Kimura, N. Katsube, T. Koike, M. Shiro and S. Aoki, Supramol. Chem., 2002, 14, 95; (e) T. Koike, T. Watanabe, S. Aoki, E. Kimura and M. Shiro, J. Am. Chem. Soc., 1996, 118, 12696; (f) A. Schrodt, A. Neubrand and R. van Eldik, Inorg. Chem., 1997, 36, 4579; (g) E. Kimura, T. Ikeda, M. Shionoya and M. Shiro, Angew. Chem., Int. Ed. Engl., 1995,34, 663.

26. B. P. Hay, M. Gutowski, D. A. Dixon, J. Garza, R. Vargas and B. A. Moyer, J. Am. Chem. Soc., 2004, 126, 7925.

27. L.-J. Yang, T. Lei, W. Liu, W.-Q. Chen, M.-S. Lin, L. Li, W. Li and Y. Li, Inorg. Chem. Commun., 2012, 21, 12.

28. T. K. Ghosh, R. Dutta and P. Ghosh, Inorg. Chem., 2016, 55, 3640.

29. B. P. Hay, D. A. Dixon, J. C. Bryan and B. A. Moyer, J. Am. Chem. Soc., 2002, 124, 182.

30. (a) J. M. Tao, J. P. Perdew, V. N. Staroverov and G. E. Scuseria, Phys. Rev. Lett., 2003, 91, 146401; (b) A. Schaefer, H. Horn and R. Ahlrichs, J. Chem. Phys., 1992, 97, 2571.

31. J. Tomasi, B. Mennucci and R. Cammi, Chem. Rev., 2005, 105, 2999.

32. (a) M. Sarma, T. Chatterjee and S. K. Das, Inorg. Chem. Commun., 2010, 13, 1114; (b) F. C. Fredrick and K. E. Johnson, J. Inorg. Nucl. Chem., 1981, 43, 1483.

33. G. Ambrosi, M. Formica, V. Fusi, L. Giorgi, A. Guerri, M. Micheloni, P. Paoli, R. Pontellini and P. Rossi, Chem. - Eur. J., 2007,13, 702.

34. D. Esteban-Gómez, L. Fabbrizzi, M. Licchelli and E. Monzani, Org. Biomol. Chem., 2005, 3, 1495.

35. M. Boiocchi, L. Del Boca, D. Esteban-Gómez, L. Fabbrizzi, M. Licchelli and E. Monzani, Chem. Eur. J., 2005, 11, 3097.

36. G. Jakab, C. Tancon, Z. Zhang, K.-M. Lippert and P. R. Schreiner, Org. Lett., 2012, 14, 1724.

37. M. Boiocchi, L. Fabbrizzi, F. Foti and A. Poggi, C. R. Chim., 2005, 8, 1519.

38. (a) R. S. Forgan, B. D. Roach, P. A. Wood, F. J. White, J. Campbell, D. K. Henderson, E. Kamenetzky, F. E. McAllister, S. Parsons, E. Pidcock, P. Richardson, R. M. Swart and P. A. 
Tasker, Inorg. Chem., 2011, 50, 4515; (b) R. S. Forgan, J. E. Davidson, F. P. A. Fabbiani, S. G. Galbraith, D. K. Henderson, S. A. Moggach, S. Parsons, P. A. Tasker and F. J. White, Dalton Trans., 2010, 39, 1763.

39. (a) J. R. Turkington, V. Cocalia, K. Kendall, C. A. Morrison, P. Richardson, T. Sassi, P. A. Tasker, P. J. Bailey and K. C. Sole, Inorg. Chem., 2012, 51, 12805; (b) P. V. R. Bhaskara-Sarma and B. R. Reddy, Miner. Eng., 2002, 15, 461; (c) H. Morizono, T. Oshima and Y. Baba, Sep. Purif. Technol., 2011, 80, 390; (d) S. Ohmuro, H. Kishi, N. Yoshihara and H. Kokusen, Talanta, 2014, 128, 102.

40. M. Tanaka, K. Koyama and J. Shibata, Ind. Eng. Chem. Res., 1998, 37, 1943.

41. (a) L. Tijoe, T. Joshi, C. M. Forsyth, B. Moubaraki, K. S. Murray, J. Brugger, B. Graham and L. Spiccia, Inorg. Chem., 2012, 51, 939.

42. (a) L. M. P. Lima, D. Esteban-Gómez, R. Delgado, C. Platas-Iglesias and R. Tripier, Inorg. Chem., 2012, 51, 6916; (b) R. D. Hancock, M. S. Shaikjee, S. M. Dobson and J. C. A. Boeyens, Inorg. Chim. Acta, 1988,154, 229.

43. (a) G. Anderegg, E. Hubmann, N. G. Podder and F. Wenk, Helv. Chim. Acta, 1977, 60, 123; (b) R. Nakon, P. R. Rechani and R. J. Angelici, J. Am. Chem. Soc., 1974, 96, 2117.

44. (a) L. M. P. Lima, D. Esteban-Gómez, R. Delgado, C. Platas-Iglesias and R. Tripier, Inorg. Chem., 2012, 51, 6916; (b) R. D. Hancock, M. S. Shaikjee, S. M. Dobson and J. C. A. Boeyens, Inorg. Chim. Acta, 1988,154, 229.

45. (a) J. K. Romary, J. D. Barger and J. E. Bunds, Inorg. Chem., 1968, 7, 1142; (b) D. W. Gruenwedel, Inorg. Chem., 1967, 7, 495.

46. R. S. Forgan, J. E. Davidson, S. G. Galbraith, D. K. Henderson, S. Parsons, P. A. Tasker and F. J. White, Chem. Commun., 2008, 4049.

47. J. Glerup, P. A. Goodson, D. J. Hodgson, K. Michelsen, K. M. Nielsen and H. Weihe, Inorg. Chem., 1992, 31, 4611.

48. P. Gans, A. Sabatini and A. Vacca, Talanta, 1996, 43, 1739.

49. SADABS, Bruker-AXS, Version 1, Bruker AXS Inc., Madison, WI, 2004.

50. G. M. Sheldrick, Acta Crystallogr., Sect. A: Fundam. Crystallogr., 2008, 64, 112.

51. L. J. Farrugia, J. Appl. Crystallogr., 1999, 32, 837.

52. DIRDIF99. P. T. Beurskens, G. Beurskens, R. de Gelder, S. García-Granda, R. O. Gould, R. Israel and J. M. M. Smits, The DIRDIF-99 program system, Technical Report of the Crystallography Laboratory, University of Nijmegen, The Netherlands, 1999.

\footnotetext{
${ }^{\dagger}$ Electronic supplementary information (ESI) available: Bond distances and angles of the metal coordination environments obtained from X-ray measurements, NMR spectra, spectrophotometric titrations, DFT structures and solvent extraction studies. CCDC 1525435-1525438. For ESI and crystallographic data in CIF or other electronic format see DOI: $10.1039 / \mathrm{c} 7 \mathrm{dt} 00093 \mathrm{f}$.
} 